\title{
Geomimicry: harnessing the antibacterial action of clays
}

\author{
LYNDA B. WILLIAMS*, \\ School of Earth \& Space Exploration, Arizona State University, Tempe, AZ 85287-1404, USA
}

(Received 4 September 2016; revised 16 January 2017; Reviews Editor: Jeff Wilson)

\begin{abstract}
A decade of research on clays that kill human pathogens, including antibiotic-resistant strains such as methicillin-resistant $S$. aureus (MRSA), has documented their common characteristics. Worldwide, $\sim 5 \%$ of clays tested to date are antibacterial when hydrated. Most antibacterial clays are from hydrothermally altered volcanics, where volcanogenic fluids produce minerals containing reduced metals. Ferruginous illite-smectite (I-S) is the most common clay mineral, although kaolins dominate some samples. Antibacterial clay mineral assemblages may contain other reduced Fe minerals (e.g. pyrite) that drive production of reactive oxygen species $\left(\mathrm{H}_{2} \mathrm{O}_{2},{ }^{\circ} \mathrm{OH},{ }^{\circ} \mathrm{O}_{2}{ }^{-}\right)$and cause damage to cell membranes and intracellular proteins. Ion exchange can also cause loss of bacterial membrane-bound $\mathrm{Ca}^{2+}, \mathrm{Mg}^{2+}$ and $\mathrm{PO}_{4}{ }^{3-}$.

Critically important is the role of clays in buffering the hydration water $\mathrm{pH}$ to conditions where $\mathrm{Al}$ and Fe are soluble. A nanometric particle size $(<200 \mathrm{~nm})$ is characteristic of antibacterial clays and may be a feature that promotes dissolution. Clay interlayers or the lumen of tubular clays may absorb reduced transition metals, protecting them from oxidation. When the clays are mixed with deionized water for medicinal applications, these metals are released and oxidized.

Different antibacterial clays exhibit different modes of action. The minerals may be a source of toxins, or by adsorption may deprive bacteria of essential nutrients. In the field, the $\mathrm{pH}$ and $\mathrm{Eh}$ (oxidation state) of the hydrated clay may help to identify potential antibacterial clays. If the $\mathrm{pH}$ is circum-neutral, toxic metals are not soluble. However, at $\mathrm{pH}<5$ or $>9$ many metals are soluble and the oxidation of transition metals increases the Eh of the suspension to $>400 \mathrm{mV}$, leading to bacterial oxidation.

Understanding the antibacterial mechanism of natural clay may lead to design of new treatments for antibiotic-resistant bacteria, with potential applications in wound dressings, medical implants (joint replacements, catheters), animal feed stocks, agricultural pathogens, and production of antibacterial building materials. This research exemplifies how 'geomimicry' (copying geochemical processes) may open new frontiers in science.
\end{abstract}

KEYwORDS: geomimicry, antibacterial clay, antibiotic resistance, hydrothermal, metal oxidation.

Clays may be considered as 'healing clay' because of the many natural attributes of their nanometric mineral assemblages that are therapeutic and promote health. When consumed by humans and animals, a practice

\footnotetext{
*E-mail: Lynda.Williams@asu.edu

${ }^{\dagger}$ George Brown Lecture, 2016, delivered at the Mid-European Clay Conference, held in Košice, Slovakia. https://doi.org/10.1180/claymin.2017.052.1.01
}

known as geophagy, the hypothesis is that the minerals provide nutrition (salt, micronutrients), soothe stomach ailments and alleviate hunger (Vermeer \& Ferrell, 1985; Wilson, 2003; Ferrell, 2008, Young, 2011). Clays are also used in wound care to stop bleeding because of their capacity to adsorb fluids and protect flesh (Williams \& Hillier, 2014) and have been used in pelotherapy (mud baths) for millennia (Carretero et al., 2013). However, there is a subset of 'healing clays' that have been identified as antibacterial, and their properties have, only 
recently, been investigated scientifically. This review focuses on a decade of antibacterial clay research.

The term 'antibacterial clay' must be defined carefully for the science-literate public because it draws from jargon traditionally specific to disciplines of geology, microbiology and medicine. A substance is referred to as antibacterial if it is effective at killing or inhibiting bacterial growth. However, no substance kills all bacteria, because bacteria are as diverse in function and adaptation as are humans. Species have evolved to thrive in a variety of environments, and some can tolerate extreme environments. An antibacterial agent is usually effective against a specific type or group of bacteria.

An antibiotic is a substance produced by a biological agent (fungi or other bacteria) which inhibits or kills certain bacterial species (Hoogerheide, 1944; Foster \& Woodruff, 2010). However, chemicals that mimic biological substances are also called antibiotics. A 'broad-spectrum' antibiotic works against a variety of bacterial species, including Gram-negative, Grampositive and mycobacterial species that each have different cell-membrane structures and genetic codes (Williams \& Haydel, 2010). We use the term antibacterial clay, as opposed to 'antibiotic', because we are studying the inorganic reactions that affect bacteria. This is sometimes called 'geomimicry' which is the design and production of materials, structures and systems that are modelled on geological entities and processes. Clay is, of course, a size term which includes the assemblage of minerals in the $<2 \mu \mathrm{m}$ size fraction (Moore \& Reynolds, 1997). By studying the processes demonstrated by natural clay deposits that inhibit or kill a broad spectrum of bacteria, one might harness the antibacterial mechanism to design new, antibacterial drugs.

This research began with the observation of an antibacterial effect of reduced-Fe bearing (green) clays from France, applied topically to treat Buruli ulcer, a necrotizing fasciitis, or 'flesh-destroying' infection (Williams et al., 2004). In 2002, Line Brunet de Courssou, a French philanthropist, travelled to the Cote d'Ivoire (Africa) on a humanitarian mission and observed many woman and children of the local tribes suffering from Buruli ulcer. This infection was first described by Sir Albert Cook in patients from Buruli County in Uganda, and the causative organism, Mycobacterium ulcerans, which is related to leprosy and tuberculosis, was isolated in 1948 by MacCallum in the Bairnsdale region of Victoria, Australia (WHO, 2008). George et al. (1999) first isolated a toxin called mycolactone, produced by Mycobacterium ulcerans and showed that it was responsible for the infection.
Women and children of the tribes investigated near Zouan Hounein (Cote d'Ivoire) are the primary 'foodgatherers' and often forage in the swamplands of the country. Certain aquatic insects (e.g. Naucoridae) have been found to harbour Mycobacterium ulcerans in glands of their pincers (Marsollier et al., 2002; Portaels et al., 2008). It is believed that bites from these insects that live near roots of swampy plants, provide a vector for transmission of this bacterium. The Mycobacterium ulcerans are slow to grow; doubling their population in vitro takes nearly one month. Those bitten by the insect might not notice an infection for months to years after the bacteria are transmitted to the skin.

Line Brunet de Courssou treated people with Buruli ulcer using poultices (hydrated clays) of French Green clay from two different suppliers in France (Argicur and Argiletz). She studied carefully their response to daily application of the clay poultices, with photographic documentation of healing the infection (Fig. 1). At the time there was no antibiotic that cured Buruli ulcer, and the most effective treatment was excision or amputation of the infected limbs. After one day of applying the Argiletz clay in hydrated form, the skin tissue was debrided with complete removal of necrotized tissue. The treatment was painful for the first week, but pain lessened as the open wounds healed (Brunet de Courssou, pers. comm.). Brunet de Courssou observed that the edges of the skin became purple, which is a pathological response to extraneous materials that become deposited in the skin or deeper tissues. When this occurred she changed to the Argicur clay, and healing proceeded over a period of several months. The healing returned the skin to a soft, supple state, with minor scarring, and returned mobility to affected joints.

Brunet de Courssou provided samples of the two French green clays she used so that we could test their mineralogical and geochemical compositions. She hypothesized that the clays might contain fibrous illite that could physically damage bacterial cells. However, scanning electron microscopy imaging of the French green clays showed that both the Argiletz and Argicur clays contained small $(\sim 200 \mathrm{~nm})$ hexagonal illite (Fig. 2). This led to our first investigation of the antibacterial effectiveness of clays (Williams et al., 2008). The World Health Organization could not help fund the treatment of Buruli ulcer with clays until there was some basic understanding of what makes the clay treatment effective. This required interdisciplinary studies of clay mineralogy, geochemistry, microbiology and medicinal response to the clay application. 


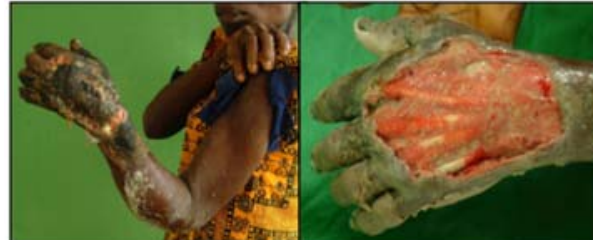

Day 1

Day 2

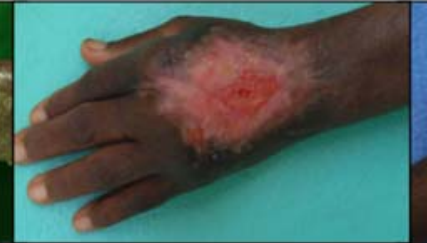

Day 103

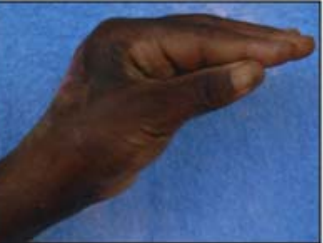

Cured

FIg. 1. Photo-documentation (by Thierry Brunet de Courssou) showing the gradual healing of Buruli ulcer infection by daily application of hydrated French green clay (modified from Williams et al., 2004).

INVESTIGATING ANTIBACTERIAL CLAYS

The approach taken to investigate the observed antibacterial action of the French green clays was to first evaluate the effectiveness of various clay samples in vitro against a broad spectrum of human pathogens (Haydel et al., 2008). The bacteria tested included common and antibiotic-resistant strains of human pathogens: E. coli (ATCC 25922), Extended Spectrum Beta Lactamase (ESBL)-resistant E. coli (ATCC 51446), Salmonella enterica serovar Typhimurium (ATCC 14028), P. aeruginosa (ATCC 27853), S. aureus (ATCC 29213), Methicillin-resistant $S$. aureus (MRSA; from Sonora Quest Laboratories; resistant to ten antibiotics; Haydel et al., 2008), Mycobacterium smegmatis (ATCC 19420), M. marinum (ATCC 927) and M. ulcerans. With the exception of the mycobacterial strains tested, the Clinical Laboratory Standards Institute (CLSI) recommends these bacteria as quality control strains for laboratory testing of antimicrobials.

Next, we determined the mineralogical composition of the French green clays to compare with their antibacterial effectiveness (Williams et al., 2008). We hypothesized that the bacteria are killed when exposed to hydrated clays either by a physical attack or by chemical transfer. It has been shown (Konhauser \& Urrutia, 1999; Wei et al., 2011) that clay minerals can adhere to bacteria by physical attraction to the bacterial membranes; enveloping them may block the uptake of nutrients and expulsion of waste products. In fact, clays can be modified to have such a large surface energy that they can kill bacteria by physically tearing cell membranes (Rossman Geise, SUNY Buffalo, pers. comm.). However, none of the antibacterial clays we have tested kills by physical destruction. Alternatively, we consider that the clays may rob bacteria of nutrients, by competition of ions for exchange sites on clay surfaces, or that the clay mineral assemblage provides toxins that overwhelm the regulatory systems of the bacteria. For example, lipid peroxidation of bacteria by oxidative stress induced by $\mathrm{Fe}$-smectites has been documented (Kibanova et al., 2009).

\section{Physical or chemical interactions}

One can measure the zeta potential of the clay and bacteria to test for physical interactions. When dealing with clay mineral assemblages, the zeta potential can be quite variable because it is an average of the multimineral suspension. Isolating each mineral component of the assemblage might bias the results; therefore we test the natural assemblage. Furthermore, it is important to simulate the chemistry of the fluid equilibrated with the mineral assemblage in order to evaluate the surface energy in the hydrated medium. Because the antibacterial clays from France were changed daily, we infer that the antibacterial process occurs within $24 \mathrm{~h}$, therefore the antibacterial clay assemblage was consistently equilibrated for $24 \mathrm{~h}$ with deionized

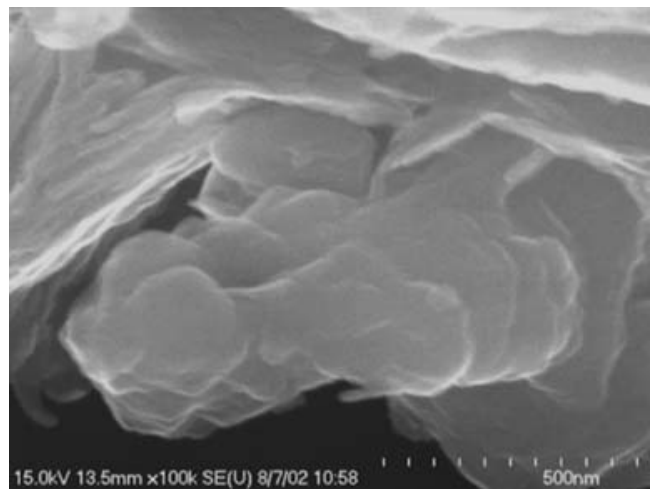

FIg. 2. SEM image of the Argicur French green clay used by Line Brunet de Courssou to treat Buruli ulcer patients. The illite forms small hexagonal plates $\sim 200 \mathrm{~nm}$ in diameter (photo by L. Williams). 
water (DIW) for our experiments. This produces an ionic strength appropriate for the zeta potential measurement. The measurements are taken over a range of $\mathrm{pH}$ in order to evaluate the energy changes resulting from attraction of $\mathrm{H}^{+}$or $\mathrm{OH}^{-}$to the mineral or bacterial surface. An example is given later for a Colombian Amazon clay (AMZ) that kills human pathogens (E. coli, B. subtilis).

Another way to test for a physical effect of clay on bacteria is by isolating the two populations. We have suspended autoclaved (sterilized) clays $(500 \mathrm{mg} / \mathrm{mL})$ in a beaker and submerged dialysis tubes (with $25 \mathrm{kDa}$ molecular weight cutoff) containing E. coli (ATCC 25922) in log phase growth, in the beaker of suspended clay (Williams et al., 2011). This allowed diffusion of elements from the hydrated clay into the bacterial suspension. After $24 \mathrm{~h}$ of incubation at $37^{\circ} \mathrm{C}$ the viability of the bacteria was tested by live/dead cell epifluorescence staining (Invitrogen; Thermo Fisher Scientific L7007). Antibacterial clays completely killed bacteria (red stained), compared to cells not exposed to the clay (green). This verified that no physical contact between the clay and bacteria was required. The bacteria were killed either by a chemical transfer of toxins to the bacteria, or loss of nutrients absorbed by the clay.

\section{Bacterial viability testing}

Standard antibacterial susceptibility testing (CLSI, 2015) was used for evaluating the effectiveness of natural clays in killing or inhibiting the growth of bacteria. Antibacterial minerals that completely kill a particular bacterial population are called bactericidal, whereas those that inhibit reproduction are called bacteriostatic. Clay that reduces the bacterial population by several orders of magnitude, compared to an untreated bacterial population, is called inhibitory. Once we identify a clay that is antibacterial we then determine the minimum inhibitory concentration (MIC), defined as the concentration that reduces a bacterial population by $50 \%$ compared to an untreated control population; and 'minimum bactericidal concentration' (MBC), defined as the concentration that kills $99.9 \%$ of the bacteria (Amyes et al., 1996).

The clay size fraction $(<2 \mu \mathrm{m})$ is separated (Moore $\&$ Reynolds, 1997) without cation exchange in order to preserve interlayer cations that may be important sources of dissolved metals. This procedure requires rinsing of salts from the sample until the clays are dispersed; therefore the sample is washed of surface components, and then dried. The dried clay sample is autoclaved $\left(121^{\circ} \mathrm{C} ; 1 \mathrm{~h}\right)$ to kill any inherent (environmental) or airborne bacteria that may settle on the sample. For initial testing, a suspension is made of $200 \mathrm{mg}$ of clay in $400 \mu \mathrm{L}$ of DIW (deionized water). The dose varies if the clay has significant smectite and forms a gel. The suspension must be dilute enough to be easily pipetted into the bacterial suspension. Bacteria are grown in a suspension in their growth media (e.g. Luria Broth; LB) at body temperature $\left(37^{\circ} \mathrm{C}\right)$ and their numbers are measured by colonyforming units (CFU) per $\mathrm{mL}$ of suspension. We start with bacteria in their 'exponential' or 'log phase' growth $\left(\sim 10^{7} \mathrm{CFU} / \mathrm{mL}\right)$, which is when they are at their healthiest life stage. When bacterial populations are too dense they reach 'stationary phase' where the population begins to die and the number of new bacteria equals the number of dead bacteria. Therefore, an overabundance of CFU is avoided by diluting the bacterial population with fresh growth media. Finally, the clay suspension (in DIW) is mixed with the bacterial suspension (in liquid growth media) in a 1:1 ratio, and incubated overnight $\left(37^{\circ} \mathrm{C}\right)$ on a rotational shaker to keep the solids suspended. Serial dilutions of the incubated suspension are made according to CLSI (2015) procedures, diluting the mixture by orders of magnitude (to $10^{-8}$ ). Each dilution is spread evenly on agar plates (petri dishes) containing the growth media, and incubated again for $24 \mathrm{~h}$, allowing the bacteria that were not damaged by the clay to grow (Fig. 3). A positive control population of the bacteria is grown in the absence of clay for comparison to the population incubated with the clay suspension. In addition, a control bacterial population is tested with standard reference clay minerals (Source Clays Repository, The Clay Minerals Society) of the dominant clay mineral in the natural sample (e.g. IMt-1 illite, SWy-1 smectite, KGa-1 kaolinite), none of which has shown antibacterial effects. The SWy-1 (Wyoming bentonite) increases bacterial growth compared to the control grown without clay (Williams et al., 2004), possibly by providing additional nutrient. The agar plates that show growth of bacterial colonies after $24 \mathrm{~h}$ of incubation are counted, with counts adjusted for the dilution factor. Experiments are always performed in triplicate (three separate preparations of the clay-bacteria mixtures), for statistical evaluation. The example (Fig. 3) comparing the antibacterial effects of the French green clays shows that the clay supplied by Argicur completely killed E. coli, whereas the Argiletz-supplied clay, and the comparable Fe-bearing illite Muloorina, did not. The geochemical differences between the French green clays are discussed later. 
a Control @ 24 h

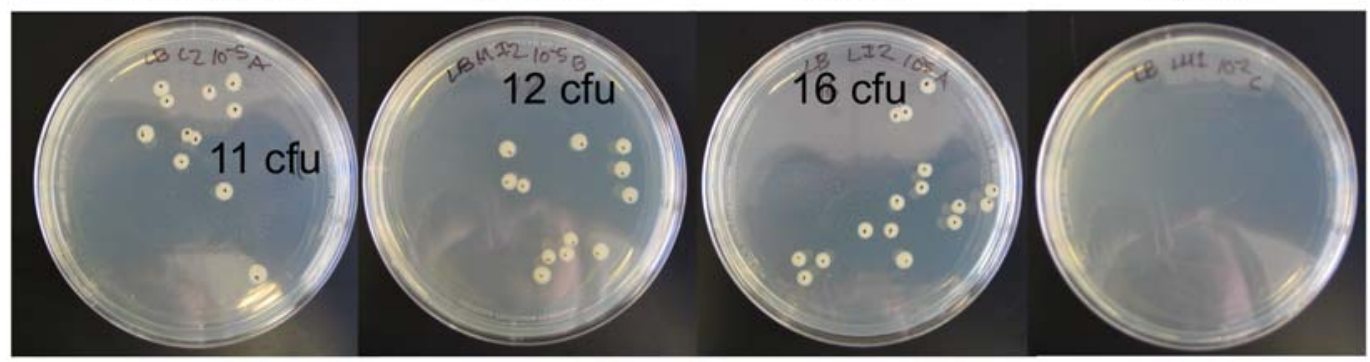

b

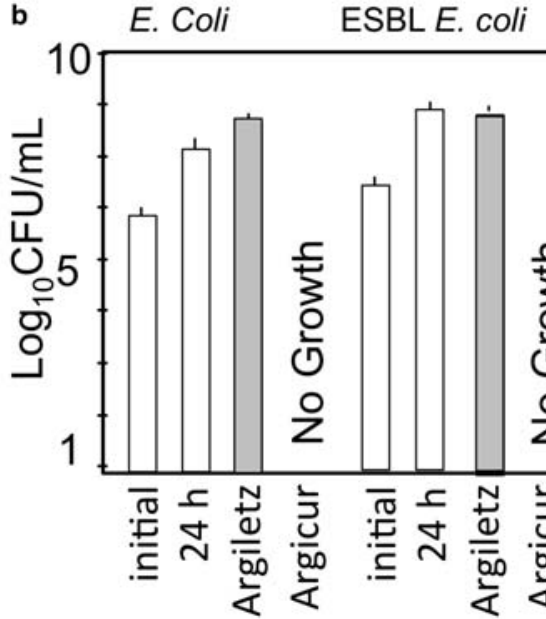

S. typhimurium

P. aeruginosa

MRSA

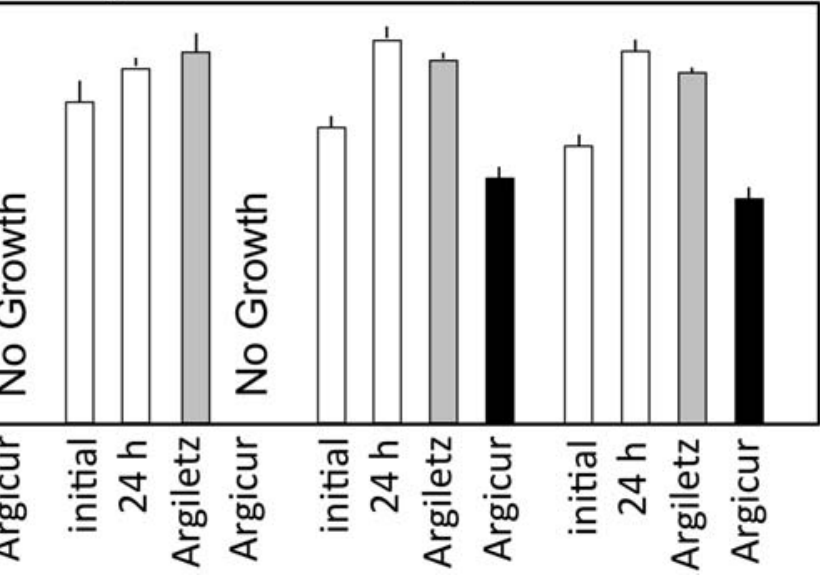

FIG. 3. Antibacterial susceptibility is determined by plate counting (CLSI, 2015). (a) Serial dilutions of E. coli incubated $\left(37^{\circ} \mathrm{C}\right)$ with clay suspensions $(24 \mathrm{~h})$ are compared to control E. coli grown without clay. (b) Bar graphs showing CFU for a variety of human pathogens tested compared to controls showing the initial and $24 \mathrm{~h}$ counts of bacteria without clay (control). All experiments were performed in triplicate using three separate preparations of the clay-bacteria suspensions.

The bacteria grown in their particular growth media (e.g. LB) is a standard microbiological method for evaluating antibacterial agents but it does not represent the geochemical conditions of a topical application of hydrated clay to the bacteria growing in wounds. In particular, if there is chemical transfer of an element derived from the clay through water to affect the bacteria, then the presence of bacterial nutrients in growth media (organic compounds, salts) will change the aqueous speciation of the fluid. Therefore, we further tested the effect of French green clays on bacteria in normal saline $(8.5 \% \mathrm{NaCl}$; isotonic solution) needed to prevent bacteria dying from osmotic shock. In every test the results show some depletion of the bacterial population due to the lack of nutrition, but dramatic killing of the bacterial populations when antibacterial clays are present (Morrison et al., 2014; Londoño \& Williams, 2016).

Aqueous leachates of the clays were prepared by equilibrating the clay with water (shaken together at $50 \mathrm{mg}$ clay/mL DIW) for $24 \mathrm{~h}$; again the reaction time was chosen to simulate the topical application of the hydrated clay poultice, which was changed daily. Elemental analyses of the leachates were conducted using inductively coupled plasma-mass spectrometry (ICP-MS) (USGS, Boulder, Colorado, USA), to look for high concentrations of known toxic elements (e.g. $\mathrm{Ag}, \mathrm{Cu}, \mathrm{Cd}, \mathrm{Se}, \mathrm{Hg}, \mathrm{As}$ ) and to determine differences in the elements derived from the two French green clays (Williams et al., 2008). Furthermore, cation exchange of the clay using $1 \mathrm{M}$ $\mathrm{KCl}\left(\mathrm{Na}, \mathrm{Ca}\right.$ and $\mathrm{NH}_{4}{ }^{+}$salts were also tested) removed 
TABLE 1. Broad-spectrum antibacterial effectiveness of the four antibacterial clays tested. The percentage of bacteria killed is indicated for variable incubation times, all at $37^{\circ} \mathrm{C}$. Initial bacterial populations were in log phase growth.

\begin{tabular}{|c|c|c|c|c|c|}
\hline Bacterial species & Time & Argicur & Argiletz & OMT & Walker \\
\hline Escherichia coli (ATCC 25922) & $24 \mathrm{~h}$ & $100 \%$ & $0 \%$ & $100 \%$ & $100 \%$ \\
\hline ESBL E. coli (ATCC 51446) & $24 \mathrm{~h}$ & $100 \%$ & $0 \%$ & $100 \%$ & $100 \%$ \\
\hline Salmonella e.s. typhimurium (ATCC 14028) & $24 \mathrm{~h}$ & $100 \%$ & $0 \%$ & $100 \%$ & $100 \%$ \\
\hline Pseudomonas aeruginosa (ATCC 27853) & $24 \mathrm{~h}$ & $100 \%$ & $0 \%$ & $100 \%$ & $100 \%$ \\
\hline Staphylococcus aureus (ATCC 29213) & $24 \mathrm{~h}$ & $92.7 \%$ & $0 \%$ & $100 \%$ & $99.1 \%$ \\
\hline Staphylococcus epidermidis (ATCC 14990) & $24 \mathrm{~h}$ & n.a. & n.a. & $100 \%$ & n.a. \\
\hline M.R.S. epidermidis (ATCC 35948) & $24 \mathrm{~h}$ & n.a. & n.a. & $100 \%$ & n.a. \\
\hline M.R.S. aureus (Sonora Quest Labs) & $24 \mathrm{~h}$ & $84 \%$ & $0 \%$ & $100 \%$ & $99.5 \%$ \\
\hline Mycobacterium smegmatis & $48 \mathrm{~h}$ & $96.8 \%$ & $0 \%$ & n.a. & n.a. \\
\hline Mycobacterium marinum & 5 days & $100 \%$ & $0 \%$ & n.a. & n.a. \\
\hline Mycobacterium ulcerans & 28 days & $99.5 \%$ & $0 \%$ & n.a. & n.a. \\
\hline
\end{tabular}

All experiments performed in triplicate. n.a. $=$ not analysed.

the exchangeable cations and the Argicur clay still proved to be antibacterial.

The results of the variable effectiveness of in vitro testing of the two French Green clays used in the treatment of Buruli ulcer (Fig. 3) show that Argicur sourced clay completely killed the Gram-negative bacterial pathogens tested, and inhibited the Grampositive $P$. aeruginosa and methicillin-resistant $S$. aureus (MRSA) by three orders of magnitude. In contrast, the Argiletz-sourced clay had no effect on the bacteria tested, within statistical uncertainty. Interestingly however, both clays were effective against $M$. ulcerans (Table 1).

\section{FRENCH GREEN CLAYS}

\section{Mineralogy}

The mineralogy of the green clay from the Argiletz (supplied in 2002) and Argicur (supplied in 2002) samples (Fig. 4) used by Brunet de Courssou in the Cote d'Ivoire, is dominated by two phases of illite, one disordered $(1 M d)$, and a $1 M$ illite-smectite with R2 ordering. Fe-rich smectite is second in abundance, comprising up to $35 \mathrm{wt} . \%$ of the Argicur. The non-clay phases in common include feldspars, micas and quartz. The one mineral that distinguishes the antibacterial

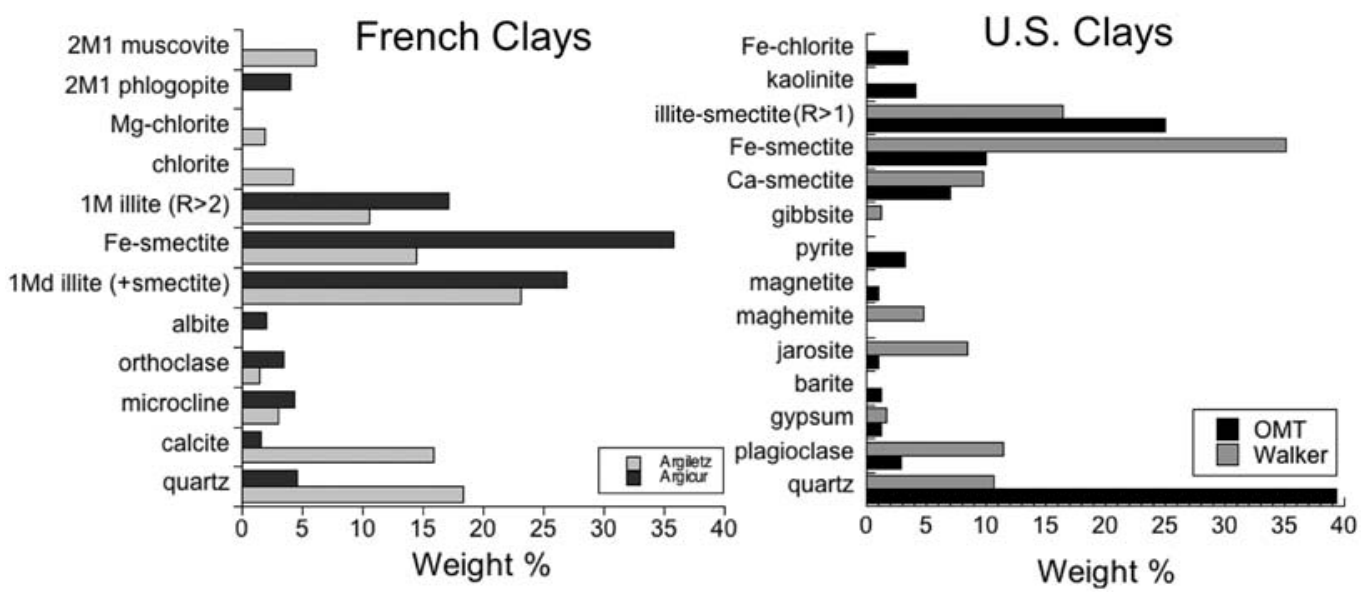

FIG. 4. Mineralogical comparisons of the two French clays and two US antibacterial clays. The mineralogy was determined by X-ray diffraction $(\mathrm{Cu}-K \alpha)$ on bulk powders, using RockJock (Eberl, 2003) for quantification. 
TABLE 2. Chemical analyses $(\mu \mathrm{g} / \mathrm{mL})$ of aqueous leachates from antibacterial clays discussed in this review.

\begin{tabular}{|c|c|c|c|c|c|}
\hline Mass/Element & Argicur & Argiletz & OMT & Walker & $\mathrm{AMZ}$ \\
\hline 7/Li & 2.8 & 0.7 & 0.6 & 0.2 & n.a. \\
\hline 9/Be & n.a. & 0.0 & 0.1 & 0.1 & n.a. \\
\hline 11/B & 9.6 & 2.6 & 0.0 & 0.1 & n.a. \\
\hline $23 / \mathrm{Na}$ & 3720 & 174 & 67 & 102 & 306 \\
\hline $24 / \mathrm{Mg}$ & 12.4 & 60.4 & 1128 & 101 & 200 \\
\hline 27/Al & 101 & 19 & 5048 & 362 & 8 \\
\hline $28 / \mathrm{Si}$ & 148 & 86 & 28.6 & 71.2 & n.a. \\
\hline $31 / \mathrm{P}$ & 8.9 & 1.2 & 278 & 3.0 & 5.3 \\
\hline $39 / \mathrm{K}$ & 154 & 246 & 35 & 62 & 1011 \\
\hline $44 / \mathrm{Ca}$ & 70 & 446 & 6618 & 4900 & 480 \\
\hline $47 / \mathrm{Ti}$ & 0.94 & 0.18 & 1.0 & 0.4 & b.d.l. \\
\hline $51 / \mathrm{V}$ & 0.43 & 0.057 & 2.0 & 0.02 & 0.5 \\
\hline $52 / \mathrm{Cr}$ & 0.026 & 0.010 & 1.0 & 0.012 & b.d.l. \\
\hline $55 / \mathrm{Mn}$ & 1.1 & 0.119 & 46 & 12 & 46 \\
\hline $56 / \mathrm{Fe}$ & 5.6 & 12.5 & 18030 & 5 & 0.6 \\
\hline $59 / \mathrm{Co}$ & 0.002 & 0.003 & 11.0 & 0.7 & 1.2 \\
\hline $60 / \mathrm{Ni}$ & 0.088 & 0.022 & 12.0 & 0.6 & 1.2 \\
\hline $63 / \mathrm{Cu}$ & 0.054 & 0.044 & 12.0 & 3.0 & 15.1 \\
\hline $66 / \mathrm{Zn}$ & 0.1 & 0.1 & 4.0 & 2.0 & 11.9 \\
\hline 69/Ga & 0.0028 & 0.0176 & 0 & 0 & n.a. \\
\hline $72 / \mathrm{Ge}$ & n.a. & 0.0004 & 0 & 0 & n.a. \\
\hline $75 / \mathrm{As}$ & 5.2 & 0.0182 & 2 & 0.01 & b.d.l. \\
\hline $77 / \mathrm{Se}$ & 0.03 & 0.12 & 0.2 & 0.01 & 5.3 \\
\hline $85 / \mathrm{Rb}$ & 0.36 & 0.129 & 0.2 & 0.10 & 1.5 \\
\hline $88 / \mathrm{Sr}$ & 1.2 & 10.4 & 27.0 & 5.0 & 7.0 \\
\hline $89 / \mathrm{Y}$ & 0.0060 & 0.0112 & 1.3800 & 0.1200 & b.d.1. \\
\hline $90 / \mathrm{Zr}$ & n.a. & 0.0190 & 0 & 0.0060 & b.d.l. \\
\hline $93 / \mathrm{Nb}$ & 0.0003 & 0.0004 & 0 & 0.002 & b.d.l. \\
\hline 95/Mo & 0.1564 & 0.0130 & 0.2000 & 0.0080 & b.d.1. \\
\hline 109/Ag & 0.0048 & 0.0001 & 0.0002 & 0.0020 & b.d.l. \\
\hline $208 / \mathrm{Pb}$ & 0.0052 & 0.0085 & 0.004 & 0.002 & b.d.l. \\
\hline 232/Th & 0.0040 & 0.0033 & 0 & 0.0040 & b.d.1. \\
\hline 238/U & 0.9800 & 0.0182 & 0.0030 & 0.0600 & b.d.l. \\
\hline $\mathrm{pH}$ & 10.2 & 7.6 & 4.2 & 4.0 & 4.3 \\
\hline Eh $(\mathrm{mV})$ & 230 & 258 & 611 & 380 & 361 \\
\hline
\end{tabular}

Analyzed by ICP-MS, $50 \mathrm{mg}$ clay/mL DIW, equilibrated for $24 \mathrm{~h}$. Analyses calibrated using the EPA method 3050B (EPA, 1996) with the average of triplicate analyses reported having relative standard deviations of $<10 \%$. n.a. $=$ not analysed.

b.d.l. $=$ below detection limit.

Argicur green clay from the non-antibacterial Argiletz green clay is calcite. Calcite makes up $>15 \mathrm{wt} . \%$ in the Argiletz, reflecting the circumneutral $\mathrm{pH}$ (7.6) buffered by that clay assemblage, where calcite is stable. However, the antibacterial Argicur clay buffers the hydrated clay suspension $(50 \mathrm{mg} / \mathrm{mL}) \mathrm{pH}$ to 10.2 where $\mathrm{Al}$, in particular, is soluble. We have found that all of the antibacterial clays buffer aqueous suspensions to $<5$ and $>9$, where $\mathrm{Al}$ is soluble, and we infer that transition metals may also be released by aluminosilicate dissolution. 


\section{Size matters}

The role of mineral dissolution as a source of toxic elements in the antibacterial process is supported by the observation that particle size influences the antibacterial effect. Only the $<0.2 \mu \mathrm{m}$ size fraction of Argicur is antibacterial (Williams et al., 2008). Detrital minerals (quartz, feldspar) dominate the coarser size fractions that are not antibacterial. Furthermore, most of the illitic crystals (illite-dominated I-S) in the $<0.2 \mu \mathrm{m}$ fraction of the Argicur are $\sim 200 \mathrm{~nm}$ in diameter (Fig. 2). In fact, this small dominant crystal size is common to all of the antibacterial clays we have studied to date. The larger relative surface area of small particles leads to more interaction with water, increasing the hydration of exchangeable metals, and also increasing the likelihood of mineral dissolution as the addition of DIW changes the equilibrium (e.g. ionic strength) of the clays taken out of their depositional environment. It has been shown that smectite dissolution occurs from edge sites of the mineral in alkaline solutions (Yokoyama et al., 2005). In particular, oxidation reactions will occur that might particularly affect reduced Fe-smectite. Given the high $\mathrm{pH}(>10)$ of the Argicur clay, when equilibrated with DIW, it is likely that some smectite dissolution occurs.

\section{Geochemistry}

The geochemistry of the two French green clays (Williams et al., 2008) differs even though the mineralogy of the two clays is very similar. Both clays contain $5-6$ wt.\% Fe in I-S. The amount of Fe is larger in the $<0.2 \mu \mathrm{m}$ size fraction as that is where the Fe-smectite and illite phases are concentrated. However, the aqueous leachates of the clays differ, particularly in terms of Al content, which is $>100 \mu \mathrm{g} / \mathrm{mL}$ in the leachates equilibrated $(24 \mathrm{~h})$ with the antibacterial Argicur clay (Table 2). The amount of known toxins such as $\mathrm{Cu}, \mathrm{Ag}$ and $\mathrm{Pb}$ are all below the MIC reported for the model bacteria tested (Nies, 1999).

Argicur Inc. (http://www.lebuissondecadouin.fr/ annuaire/argicur/) could not reveal the geological source of the green clay used by Brunet de Courssou in the treatment of Buruli ulcer. All of their clay products were sampled and tested again in 2005, including the stockpile of green clay that was used for Buruli treatments and provided for our testing in 2002. However, none of the 2005 samples showed any antibacterial effect, even though the original samples provided to us in 2002 are still antibacterial. Two possible reasons for this are proposed. One is that the clay stockpile was outdoors, exposed to precipitation for $5 \mathrm{y}$, which probably oxidized the clay (although it was still green in colour). In addition, chemical additives (e.g. $\mathrm{NaHCO}_{3}$ ) were applied to the clay to increase its heat capacity for use in spas, and may have altered the interlayer chemistry, removing important exchange cations, altering the surface energy of the clay, and changing the $\mathrm{pH}$, all of which may have eliminated the antibacterial effect.

\section{U.S. ANTIBACTERIAL CLAYS: HYDROTHERMAL DEPOSITS}

Without knowing the geological/depositional environment of the antibacterial French green clay, we attempted to identify other antibacterial clays that might provide accessible depositional environments to study. A survey of on-line 'healing clays', clay repository standard reference clays, and dozens of samples from oil companies, clay industries worldwide, and private land owners showed only $\sim 5 \%$ that were antibacterial. One particular Blue clay deposit from Douglas Co., Oregon (USA) was the most effective antibacterial clay we have found, killing $100 \%$ of the broad-spectrum of bacteria tested (Table 1), including antibiotic-resistant strains (Morrison et al., 2016). Rogue Silicates Inc. leases the mineral rights to the deposit, and Oregon Mineral Technologies (OMT) developed the deposit. OMT supported our study of the depositional environment of their antibacterial clay by allowing access and facilities for the field work.

Another antibacterial clay was identified from the Walker Lake region of Nevada. This clay was originally marketed by Miraculite LLC, and has been sold as a dietary supplement for Fe under the name SierraSil ${ }^{\circledR}$. We have not studied this clay depositional environment, but the location, mineralogy and antibacterial effect were comparable to the results for the Oregon Blue clay. In this text we refer to the Nevada deposit as the Walker clay. Table 1 compares the antibacterial effects of the OMT and Walker clays on a broad spectrum of bacterial pathogens. Both are antibacterial at the concentration tested $(100 \mathrm{mg} / \mathrm{mL})$, but the OMT is more effective against MRSA.

\section{Mineralogical comparison}

The mineralogy of these two US antibacterial deposits (Fig. 4) shows that mixed-layered illitesmectite dominates these clays, and they also contain discrete $\mathrm{Ca}$ - and $\mathrm{Fe}$-smectites, minor kaolinite and chlorite. Like the French green clays, the deposit 

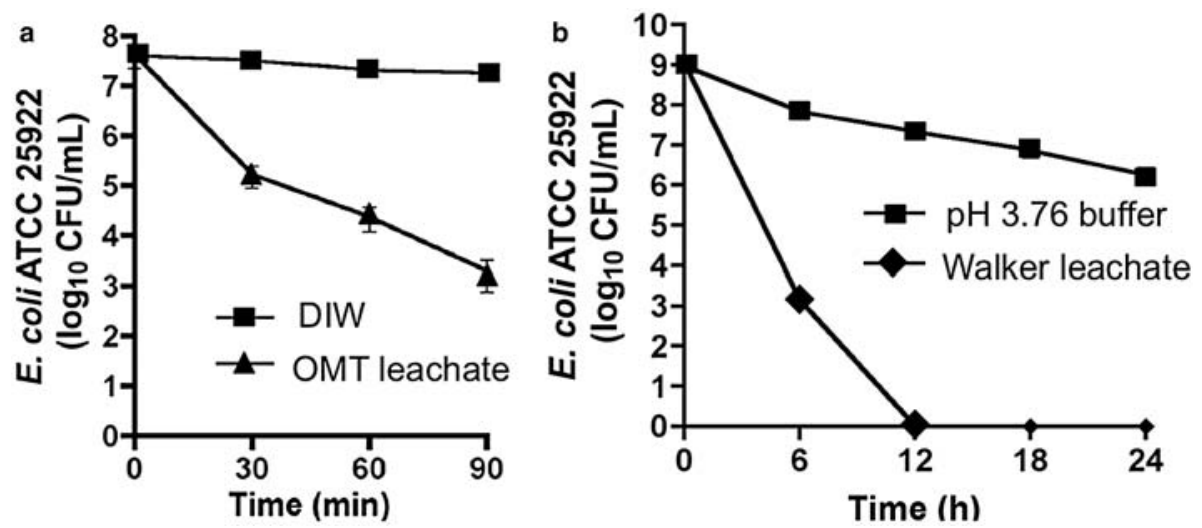

FIG. 5. Antibacterial effect of aqueous leachates on E. coli over time comparing: (a) OMT to DIW; and (b) Walker to DIW buffered at $\mathrm{pH} 3.76$, the $\mathrm{pH}$ of the leachate. The rapid decline in bacteria treated with leachates compared to water alone and bacteria in acidified water indicates that $\mathrm{pH}$ alone is not killing the $E$. coli.

contains considerable feldspar and secondary quartz from the hydrothermal alteration of andesite porphyry (Morrison et al., 2014). Of importance are minor amounts of reduced Fe-bearing phases including pyrite, magnetite and maghemite. The presence of gypsum indicates a sulfate-rich environment consistent with magmatic fluid inputs from the primary igneous source (Morrison et al., 2014).

The aqueous leachates of the OMT and Walker clays are both antibacterial (Fig. 5). However the OMT leachate completely kills model E. coli (ATCC 25922) within $90 \mathrm{~min}$, while the Walker leachate takes $12 \mathrm{~h}$. The chemistry of the aqueous leachates of these clays (Table 2) shows that both are high in $\mathrm{Mg}, \mathrm{Al}$ and $\mathrm{Ca}$, but the OMT leachate is extraordinarily high in Fe. This supports the conclusion that the aluminosilicates containing reduced $\mathrm{Fe}$, and possibly other transition metals, seem to be involved in the antibacterial effectiveness. Therefore, we mapped the mineralogical and geochemical properties of the various clay alteration assemblages found in the OMT deposit and compared their antibacterial effectiveness (Morrison et al., 2014; Morrison 2015).

\section{Oregon blue clay}

The OMT deposit is located $\sim 30 \mathrm{~km}$ west of Crater Lake, Oregon (Fig. 6), but it is associated with

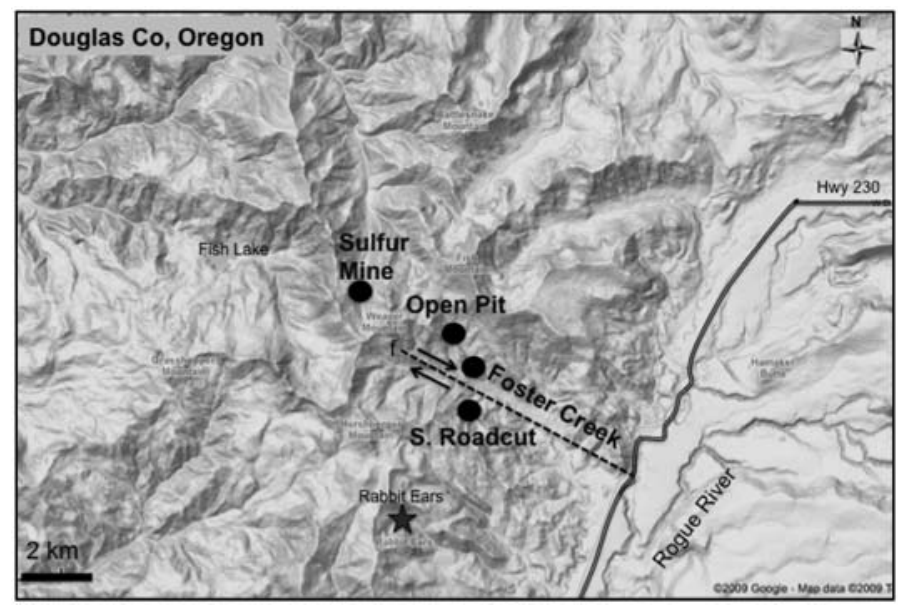

FIG. 6. Field area of the Oregon Mineral Technologies deposit and major sites sampled. 


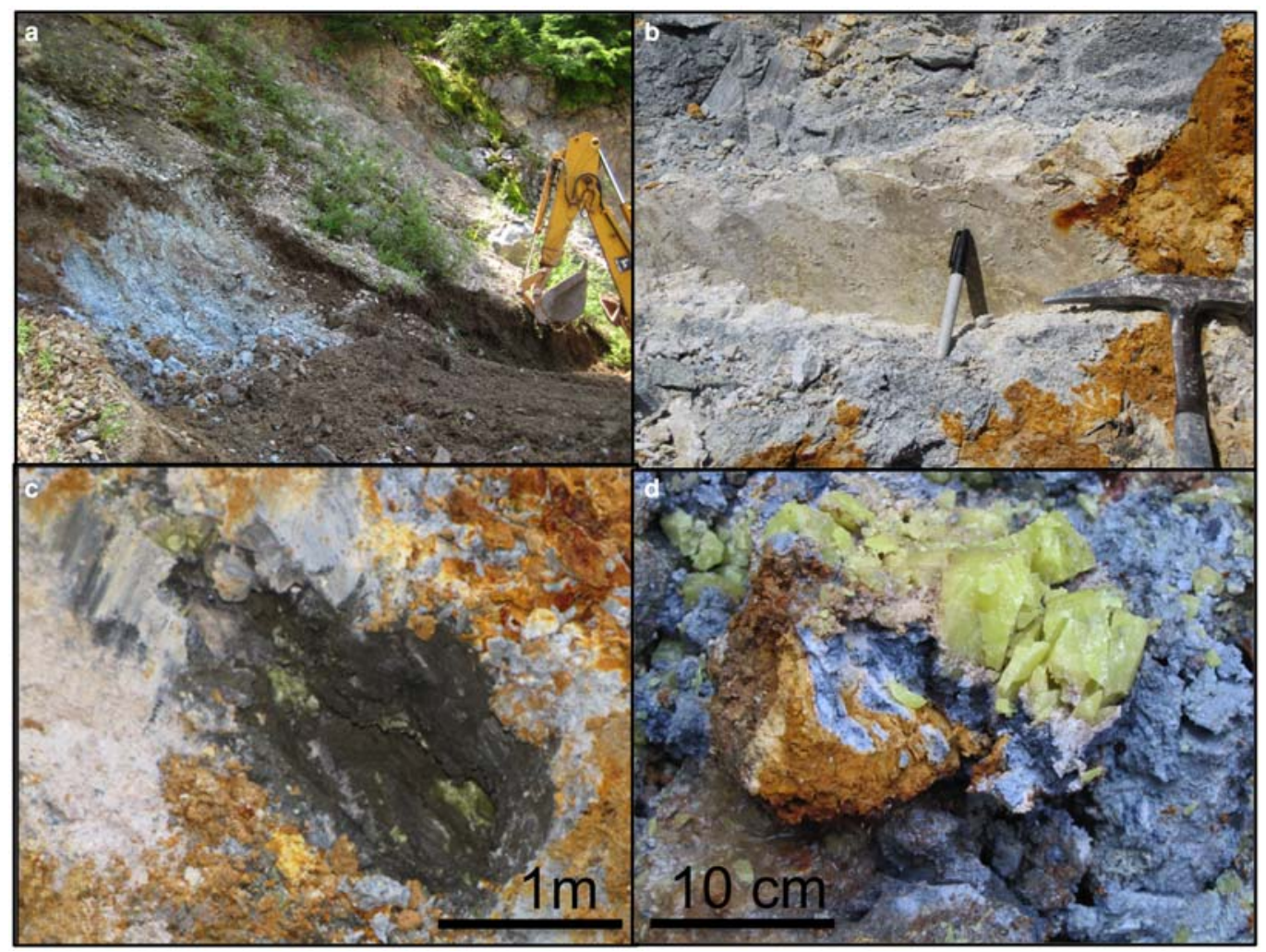

FIG. 7. Clay alteration assemblages studied in the OMT deposit. (a) Blue clay, (b) White clay in fault zones, (c) Black clay rich in pyrite, (d) Red oxidized surface clay found at all locations and elemental sulfur from the Sulfur mine location (photos by K.D. Morrison, 2015).

volcanics that are $\sim 30$ Ma older than the eruption of Mt. Mazama that formed Crater Lake (Bacon \& Nathenson, 1996). The dominant host rock of the region is a porphyritic andesite, capped by younger basalts. A major fault runs NW-SE through the region focusing drainage down the Foster Creek, which drains into the $\mathrm{N}-\mathrm{S}$ trending Rogue River. The OMT Blue clay is exposed in several areas across this valley, and deeper (hotter) parts of the deposit are found to the NW where sulfur was mined in the 1900s. An open pit mine exposed the relationship of several clay alteration zones in this deposit. The dominant Blue clay is a hydrothermal alteration product of the andesite porphyry that contains 4-6 wt.\% pyrite. Beneath this, exposed primarily in the Sulfur mine region, is a Black clay that has large amounts of pyrite $(\sim 9 \mathrm{wt} . \%)$ intermixed with Blue and White clays, with large crystals of elemental sulfur precipitated in late (cooling) stages of the hydrothermal alteration (Fig. 7). The faults that run through the open pit and regionally trend NW-SE are associated with White clays bearing smectite, but no pyrite. These 'bleached' clays are interpreted to have formed from meteoric water percolating through the faults as the system cooled (Morrison et al., 2014; Morrison, 2015). Red clays at the surface contain goethite from oxidation of the pyrite-rich Blue clays.

\section{Regional antibacterial testing}

For rapid assessment of large numbers of clay samples it was not practical to perform antibacterial susceptibility by plate counting. Instead, Kirby-Bauer disk diffusion methods were modified (Bauer et al., 1966) for antibacterial mineral mapping. Using model E. coli (ATCC 25922) grown in agar with LB growth media $(10 \mathrm{~g} \mathrm{LB} / \mathrm{mL}), 8 \mathrm{~mm}$ round wells perforating the agar (4 $\mathrm{mm}$ deep), were filled with hydrated clays $(100 \mathrm{mg} / \mathrm{mL})$ and incubated at $37^{\circ} \mathrm{C}$ for $24 \mathrm{~h}$. The diffusion of elements into the bacteria creates a 'zone 


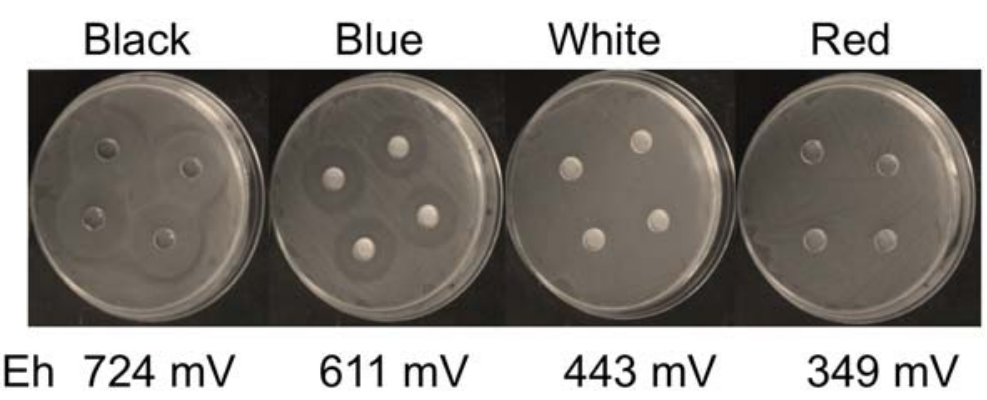

FIG. 8. Zones of E. coli growth inhibition by disk diffusion away from hydrated clays taken from the major alteration assemblages identified in the OMT deposit.

of growth inhibition' around the wells, and, by measuring the diameter of the inhibited growth zone, one can approximate the antibacterial effectiveness. An example of the disk diffusion method (Fig. 8) is shown for the four major clay alteration zones. The Black clay containing the most pyrite shows the greatest antibacterial effect and the Red oxidized clay shows no zone of inhibition.

\section{Mineralogy}

Quantitative mineralogy was determined by X-ray diffraction on random bulk powders of the clay samples using alumina as an internal standard and RockJock 11 interpretive software (Eberl, 2003). Table 3 shows the bulk powder mineralogy for each of the major clay alteration zones. This comparison shows that the most antibacterial zones (Black and Blue) contain pyrite; however, the White clay also inhibits bacterial growth, but does not contain detectable amounts of pyrite. Notably, the White clay contains variable amounts of smectite, which may act as a reservoir for reduced $\mathrm{Fe}$ released from pyrite that may have dissolved during the bleaching process (meteoric water percolation). Other important observations are that the Blue and White zones contain gypsum, indicative of the oxidation of sulfides. The Red clay contains goethite, indicating the complete oxidation of $\mathrm{Fe}^{2+}$ to $\mathrm{Fe}^{3+}$, and calcite indicating that the $\mathrm{pH}$ must be $>7$. The $\mathrm{pH}$ and Eh (average values) for each clay zone are noted at the bottom of Table 3 . As a reminder, these values were measured on the clay after hydration with DIW at the constant ratio of $50 \mathrm{mg}$ clay/ $\mathrm{mL}$, equilibrated for $24 \mathrm{~h}$. The $\mathrm{pH}$ of the clay suspension increases from $\sim 2$ in the Black clays deep in the hydrothermal system to $\sim 7$ in the Red clay at the surface. Conversely, the Eh decreases from $>700 \mathrm{mV}$ in the Black clay to $\sim 350 \mathrm{mV}$ in the surficial Red clay.
X-ray diffraction patterns of the ethylene glycolsaturated, oriented, clay-size $(<2 \mu \mathrm{m})$ fraction from the various alteration zones of the OMT deposit (Fig. 9) were interpreted using Sybilla (Zeelmaekers et al., 2009). As shown by the bulk powder XRD, the dominant clay minerals in each alteration zone are I-S, but the \%I and I-S ordering vary, primarily reflecting temperature variations. The most abundant clay is rectorite in the Blue clay alteration zone, an R1 ordered I-S with 55\%I (Morrison et al., 2014). Other outcrops of the Blue clay have $70 \% \mathrm{I}$ in I-S plus discrete smectite, with up to $85 \% \mathrm{I}, \mathrm{R} 3$ ordered I-S in a road-cut exposure south of the open pit indicating higher temperatures. The Black clay from the Sulfur Mine

TABLE 3. Bulk mineralogical composition of the four alteration zones in the OMT deposit (wt.\%).

\begin{tabular}{lcccc}
\hline Mineral & Black & Blue & White & Red \\
\hline $\begin{array}{l}\text { Non-clays } \\
\quad \text { quartz }\end{array}$ & 11.3 & 42.2 & 50.0 & 36.3 \\
plagioclase & 4.8 & 2.5 & 3.0 & 4.6 \\
$\begin{array}{l}\text { pyrite } \\
\text { sulfur }\end{array}$ & 9.0 & 3.1 & & \\
$\begin{array}{l}\text { gypsum } \\
\text { goethite }\end{array}$ & 47.0 & & & \\
$\quad$ calcite & & 1.2 & 2.8 & \\
$\begin{array}{l}\text { Clays } \\
\text { illite-smectite }\end{array}$ & 27.8 & 51.1 & 37.7 & 44.6 \\
$\begin{array}{l}\text { smectite } \\
\text { kaolinite }\end{array}$ & & & 6.5 & \\
$\begin{array}{l}\text { chlorite } \\
\text { pH }\end{array}$ & & & & 4.7 \\
Eh $^{\mathrm{a}}(\mathrm{mV})$ & 2.0 & 2.9 & 4.2 & 3.5 \\
& 724 & 611 & 443 & 349 \\
\hline
\end{tabular}

${ }^{a} 50 \mathrm{mg}$ clay $/ \mathrm{mL}$ DIW equilibrated for $24 \mathrm{~h}$. 


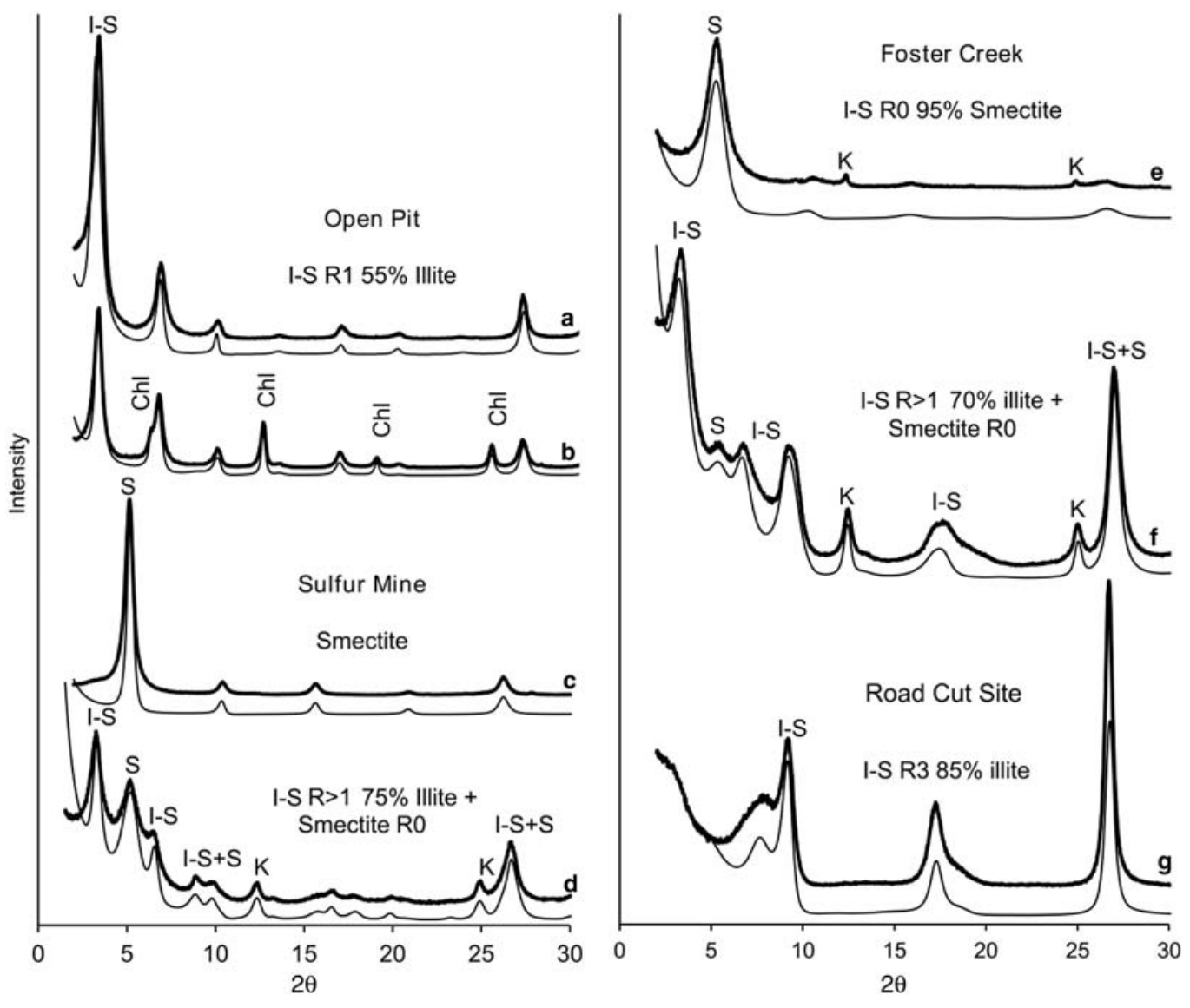

FIG. 9. XRD patterns of oriented, ethylene glycol-saturated $<2 \mu \mathrm{m}$ size fraction separates from (a) Open Pit Blue clay, (b) Open Pit perimeter, (c) Sulfur Mine White clay, (d) Sulfur mine Blue clay, (e) Foster Creek White clay, (f) Foster Creek Blue clay, (g) Roadcut Blue clay (Sample locations in Fig. 6; data from Morrison, 2015).

region contains $70 \% \mathrm{I}$ in $\mathrm{I}-\mathrm{S}(\mathrm{R}>1)$. Finally the White clay, associated with fault traces, grades from pure smectite where the fluid:rock ratio is high, and temperatures relatively low, to more I-S approaching the country rock that experienced higher temperatures through hydrothermal alteration. Some regions exhibit minor kaolinite and chlorite.

It appears that a combination of the clay minerals, which serve as the dominant $\mathrm{pH}$ buffer for fluids, and phases that contribute reduced $\mathrm{Fe}$ (e.g. pyrite) or other redox reactive metal, act to create an antibacterial mineral assemblage. There are two forms of pyrite in this deposit; one is a crystalline pyrite with crystals $>10 \mu \mathrm{m}$ in diameter and the other is sub-micron spherical pyrite physically intermixed with clay minerals (Fig. 10). Figure 11 shows a high-resolution SEM image of the Blue clay containing small rod-shaped features $(1 \mu \mathrm{m}$ long) that look like bacteria. These bodies have concentrated $\mathrm{Fe}$ and $\mathrm{S}$ according to EDX-ray maps, and supported by NanoSIMS ion imaging (data not shown). RNAwas extracted from the inherent environmental bacteria found in fresh samples taken from the Blue clay in the open pit and 19 nucleotide sequences of the taxa were analysed for genetic evolutionary relationships (Weimin Gao, Arizona State University Biodesign Institute, USA, pers. comm.). The dominant environmental bacteria living in this clay are from the genus Burkholdaria with 12 taxanomic subunits. These are CO-oxidizing, mixotrophic acidophiles common in volcanic soils (King et al., 2008; Weber \& King, 2010) and some species are known to accumulate $\mathrm{Fe}$ aggressively (Kvitko et al., 2012). These environmental microbes may provide nucleation sites for accumulation of the 


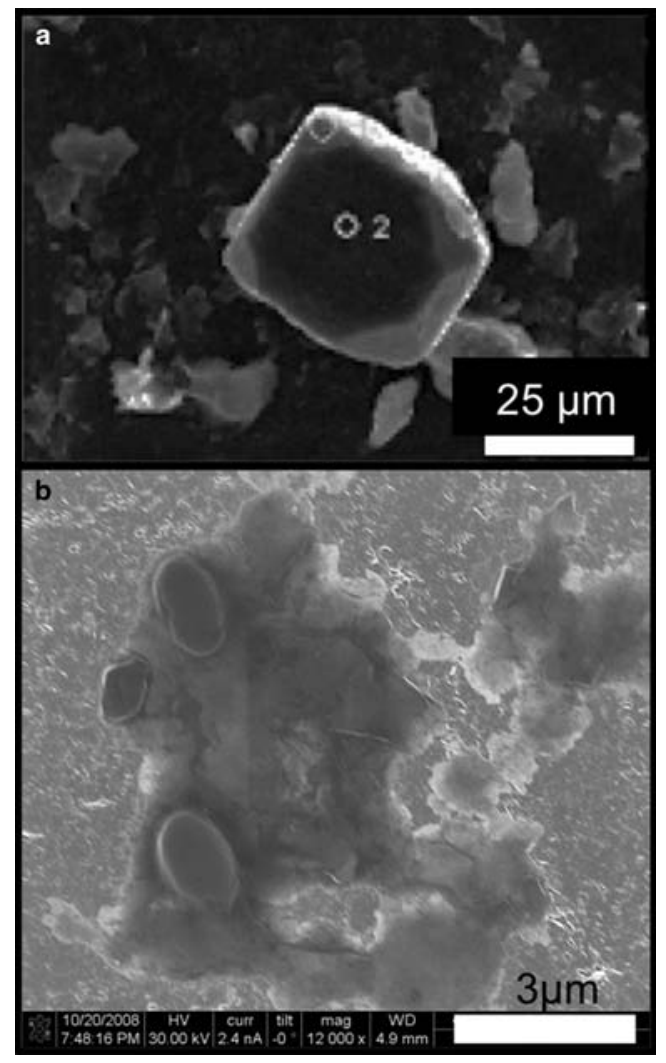

FIG. 10. Pyrite morphologies in the OMT Blue clay alteration assemblage. (a) Crystalline pyrite is $>10 \mu \mathrm{m}$ across, whereas (b) $<1 \mu \mathrm{m}$ Fe-S-bearing spheres are abundant in the clay matrix (Williams et al., 2011).

sub-micron pyrite that is more soluble under oxidizing conditions than the larger crystalline pyrite, and may contribute to the large amount of $\mathrm{Fe}^{2+}$ in the Blue clay aqueous leachate.

\section{Oxidation states of minerals and hydration water}

Important information about the antibacterial process was derived from sampling the Blue clay in the open pit mine, with depth from surface (Fig. 12). Samples were taken at intervals down to $1.5 \mathrm{~m}$ and their mineralogy, geochemistry and antibacterial effectiveness were compared. Samples were also taken from the surficial Red clay, a fault zone containing White clay, and the stockwork veins of quartz and pyrite that underlie the deposit (Morrison, 2015). The antibacterial effectiveness of each sample was determined using $100 \mathrm{mg}$ clay/mL, which was determined by plate counting to be the MBC. Samples from the surface-oxidized Red clay showed no antibacterial effect, as expected. However, within the Blue clay the antibacterial effect decreased with increasing burial depth. This was an unanticipated trend, given that the Black clay from the Sulfur Mine which contained 9 wt. $\%$ pyrite was the most antibacterial (produced the largest zone of inhibition; Fig. 8). Within the Blue clay, Morrison (2015) found the greatest antibacterial effect in samples with higher oxidation states (Eh up to $725 \mathrm{mV}$ ). His work shows that it is not the amount of pyrite in the clay, but rather the oxidation state of the hydrated pyrite-bearing clay that drives the antibacterial process. The samples deeper in the pit are less oxidized, with Eh values closer to $400 \mathrm{mV}$, and are less thus effective at killing bacteria. Presumably, these deeper samples would be more effective antibacterial agents as they become more oxidized (surface exposure over time, or by addition of dissolved $\mathrm{O}_{2}$ ).

The White clay from the exposed fault (Fig. 12) contains no pyrite, but it is inhibitory to bacterial growth $(\mathrm{pH} \approx 4.2 ; \mathrm{Eh} \approx 450)$. Samples from the stockwork veins composed primarily of hydrothermal quartz and crystalline pyrite are not antibacterial. Although pyrite is a source of dissolved $\mathrm{Fe}^{2+}$, it appears that the more crystalline forms $(>10 \mu \mathrm{m})$ are not soluble enough to provide a sufficient supply of $\mathrm{Fe}^{2+}$ to kill E. coli. We hypothesize that the presence of expandable clay minerals (I-S) is important for buffering the $\mathrm{pH}$ to conditions where $\mathrm{Fe}^{2+}$ is soluble from the sub-micron pyrite, and potentially the clays stabilize $\mathrm{Fe}^{2+}$ in their interlayers, which act as a reservoir of the reduced $\mathrm{Fe}$ that is released upon addition of DIW. In other words, the expandable clays may act as a capsule for extended release of antibacterial agents. What is most important is the oxidation state during the reaction of $\mathrm{Fe}^{2+}$ to $\mathrm{Fe}^{3+}$. In the Red clay, the oxidation state of the minerals reaches $>800 \mathrm{mV}$, where $\mathrm{Fe}^{3+}$ is stable and goethite precipitates. Therefore, the hydrated Red clay has no mineral drive for oxidation reactions with DIW and the antibacterial action ends.

\section{Role of reactive oxygen species}

Morrison et al. (2016) presented analysis of the antibacterial mechanism and the role of reduced $\mathrm{Fe}$ in the OMT antibacterial clay. Reactive oxygen species (ROS) are formed during the oxidation of pyrite (Schoonen et al., 2010) following the well known Fenton reaction series (Fenton, 1894). Either dissolved 


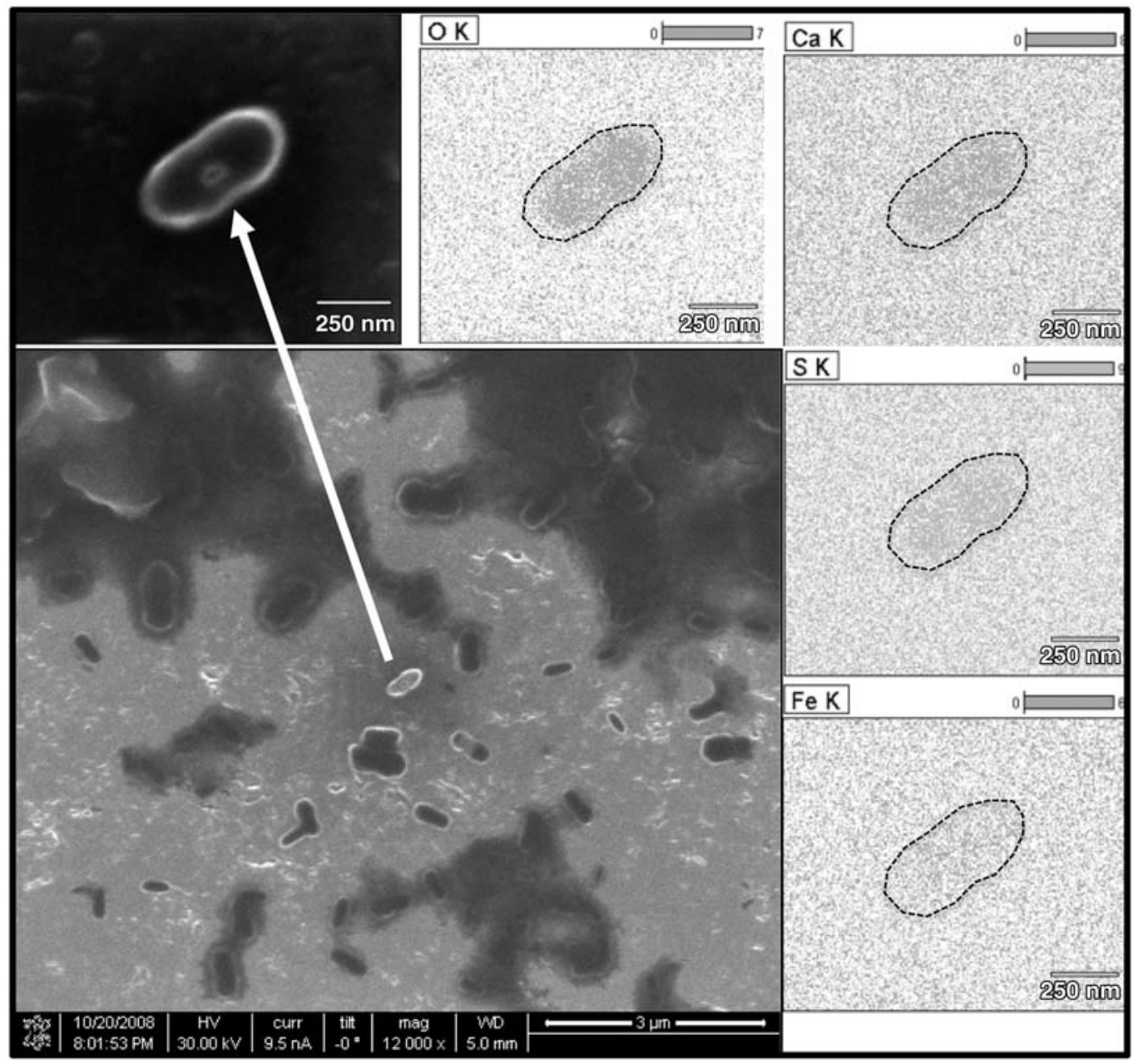

FIG. 11. SEM and energy dispersive X-ray maps showing microbe-shaped bodies, in the OMT Blue clay, which concentrate $\mathrm{O}, \mathrm{Ca}, \mathrm{S}$ and $\mathrm{Fe}$. These are interpreted as environmental microbes which metabolize and concentrate $\mathrm{Fe}^{2+}$.

$\mathrm{O}_{2}$ or $\mathrm{Fe}^{3+}$ can oxidize sulfur in pyrite when hydrated with DIW (Rimstidt \& Vaughan, 2003):

$\mathrm{FeS}_{2}+3.5 \mathrm{O}_{2}+\mathrm{H}_{2} \mathrm{O} \rightarrow \mathrm{Fe}^{2+}+2 \mathrm{SO}_{4}{ }^{2-}+2 \mathrm{H}^{+}$

(if dissolved $\mathrm{O}_{2}$ is the oxidant)

$$
\mathrm{Fe}^{2+}+\mathrm{O}_{2}+4 \mathrm{H}^{+} \rightarrow \mathrm{Fe}^{3+}+2 \mathrm{H}_{2} \mathrm{O}
$$

$$
\text { (oxidation of dissolved } \mathrm{Fe}^{2+} \text { by } \mathrm{O}_{2} \text { ) }
$$

$\mathrm{FeS}_{2}+14 \mathrm{Fe}^{3+}+8 \mathrm{H}_{2} \mathrm{O} \rightarrow 15 \mathrm{Fe}^{2+}+2 \mathrm{SO}_{4}{ }^{2-}+16 \mathrm{H}^{+}$

(if dissolved $\mathrm{Fe}^{3+}$ is the oxidant)

During the dissolution of pyrite, intermediate reactions produce ROS-containing radical molecules
(Friedlander et al., 2015) or ferryl ion $\left(\mathrm{FeO}^{2+}\right.$; Barbusinski, 2009), both oxidants that are destructive to biomolecules:

$$
\begin{gathered}
\mathrm{Fe}^{2+}+\mathrm{O}_{2} \rightarrow \mathrm{Fe}^{3+}+\mathrm{O}_{2}^{-} \\
\mathrm{Fe}^{2+}+\mathrm{O}_{2}{ }^{-}+2 \mathrm{H}^{+} \rightarrow \mathrm{Fe}^{3+}+\mathrm{H}_{2} \mathrm{O}_{2} \\
\mathrm{Fe}^{2+}+\mathrm{H}_{2} \mathrm{O}_{2} \rightarrow \mathrm{Fe}^{3+}+\mathrm{OH}^{-}+\cdot \mathrm{OH}
\end{gathered}
$$

The reaction series 7 represents a stepwise one-electron reduction of dissolved oxygen (Prousek, 2007) as a reduced metal $\left(\right.$ e.g. $\left.\mathrm{Fe}^{2+}\right)$ is oxidized:

$$
\mathrm{O}_{2} \rightarrow \mathrm{O}^{-}{ }^{-} \rightarrow \mathrm{H}_{2} \mathrm{O}_{2} \rightarrow{ }^{\cdot} \mathrm{OH} \rightarrow \mathrm{H}_{2} \mathrm{O}
$$




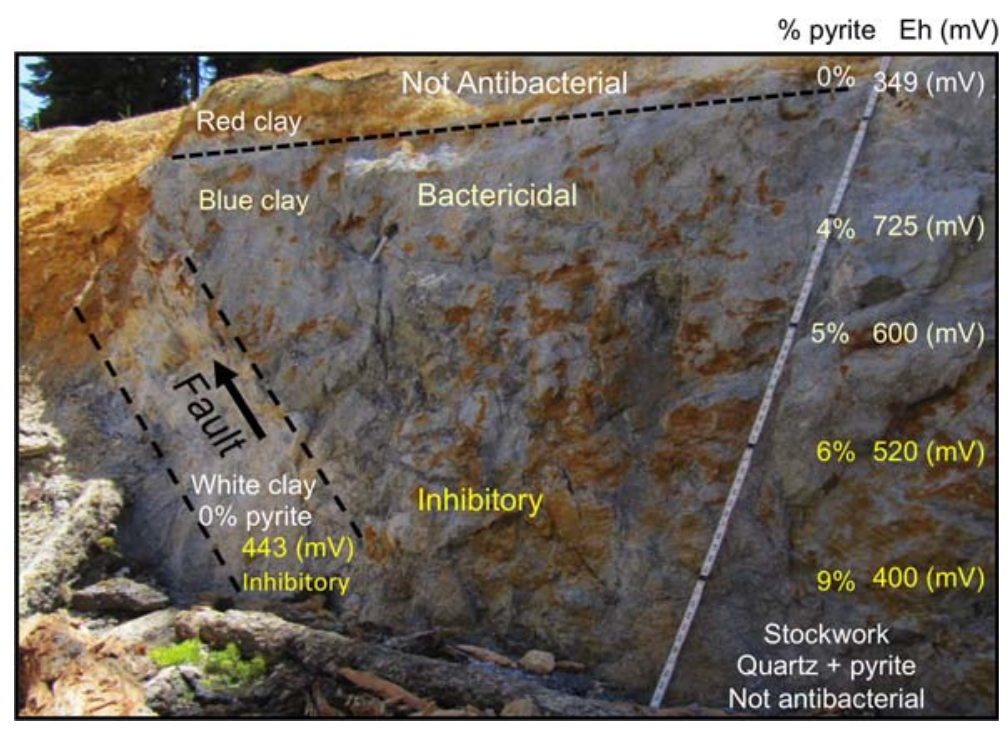

FIG. 12. Cross section sampled through the OMT Blue clay in the Open Pit reveals that the antibacterial effectiveness decreases with depth as the oxidation state of the hydrated clay decreases. The pyrite content increases with depth, but is negatively correlated with bactericide. Oxidation state is the dominant control on the antibacterial process.

Therefore, production of hydrogen peroxide $\left(\mathrm{H}_{2} \mathrm{O}_{2}\right)$, a stable molecule, can be used as a proxy for the production of hydroxyl radical ( $\left.{ }^{\circ} \mathrm{OH}\right)(\mathrm{Cohn}$ et al., 2005), which is a species that has a very short existence $\left(10^{-9} \mathrm{~s}\right.$ half life), reacting within a few nanometers of where it forms (Winterbourn, 2008). Cohn et al. (2005) described a method using leuco-crystal violet and horseradish peroxidase to measure the production of $\mathrm{H}_{2} \mathrm{O}_{2}$ from minerals. Measurements of $\mathrm{H}_{2} \mathrm{O}_{2}$ produced by OMT clay suspensions show trends that correlate with metal solubility.

The antibacterial activity of the OMT clays was measured in outcrops across the entire deposit, using zone of inhibition testing as an indicator of bactericidal effectiveness. The diameter of growth inhibition (mm) was measured on $100 \mathrm{mg}$ clay/mL suspensions of clay in disk diffusion wells (Fig. 8) and trends were observed as a function of $\mathrm{pH}$ (Fig. 13). Both the Gram-negative and Gram-positive model bacteria (E. coli and $S$. epidermidis, respectively) showed the greatest bactericide at low $\mathrm{pH}(<5)$, but no effect as the $\mathrm{pH}$ increased into the calcite stability region. Coincident with this $\mathrm{pH}$ increase, Morrison et al. (2016) observed a decrease in the concentration of $\mathrm{Fe}^{3+}, \mathrm{Fe}^{2+}$ and $\mathrm{Al}^{3+}$, the dominant aqueous metals in the leachate. Pourbaix stability diagrams for Fe-S-O and Al-O-H (at $25^{\circ} \mathrm{C}$ ) were used to indicate the aqueous speciation of OMT clay suspensions relative to their antibacterial effectiveness (Fig. 14). Only those clays buffering fluid $\mathrm{pH}$ and $\mathrm{Eh}$ in the stability fields for aqueous $\mathrm{Fe}^{2+}$ and $\mathrm{Al}^{3+}$ are antibacterial. Measurements of hydrogen peroxide $\left(\mathrm{H}_{2} \mathrm{O}_{2}\right)$ followed the concentrations of the metals, decreasing from $\sim 1500 \mu \mathrm{M}$ at $\mathrm{pH} 2.5$ to $0 \mu \mathrm{M}$ at $\mathrm{pH}$ 5. E. coli cells are affected by $\mathrm{H}_{2} \mathrm{O}_{2}$ concentrations greater than $25 \mu \mathrm{M}$ and $\sim 100 \mu \mathrm{M}$ is needed to achieve significant bacterial mortality (Hyslop et al., 1995).

Using the production of $\mathrm{H}_{2} \mathrm{O}_{2}$ as an indicator of the presence (and reactivity) of dissolved $\mathrm{Fe}^{2+}$, Morrison et al. (2016) evaluated the concentration of $\mathrm{H}_{2} \mathrm{O}_{2}$ in a time series for clay suspensions compared to aqueous leachates alone. The concentration of the clay $(20 \mathrm{mg}$ clay $/ \mathrm{mL}$ ) was the same as the leachate $(20 \mathrm{mg}$ clay $/ \mathrm{mL}$, equilibrated for $24 \mathrm{~h}$, then separated). The results showed that the clay suspension generates ROS continuously over $24 \mathrm{~h}$, whereas the aqueous leachate loses its ability to produce ROS in $<1 \mathrm{~h}$ (data not shown). This points to the importance of the clay as a continuous source of reactants and in buffering the $\mathrm{pH}$ to conditions that keep $\mathrm{Fe}^{2+}$ stable and soluble. If $\mathrm{Fe}^{2+}$ is absorbed into the smectite interlayers it may be released slowly over an extended time promoting long-lasting antibacterial effects compared to metal solutions alone. To test this, Morrison (2015) saturated the non-antibacterial SWy-1 smectite with $1 \mathrm{M} \mathrm{FeCl}_{2}$, and found that the addition of interlayer $\mathrm{Fe}^{2+}$ to the smectite made it antibacterial (data not shown). 

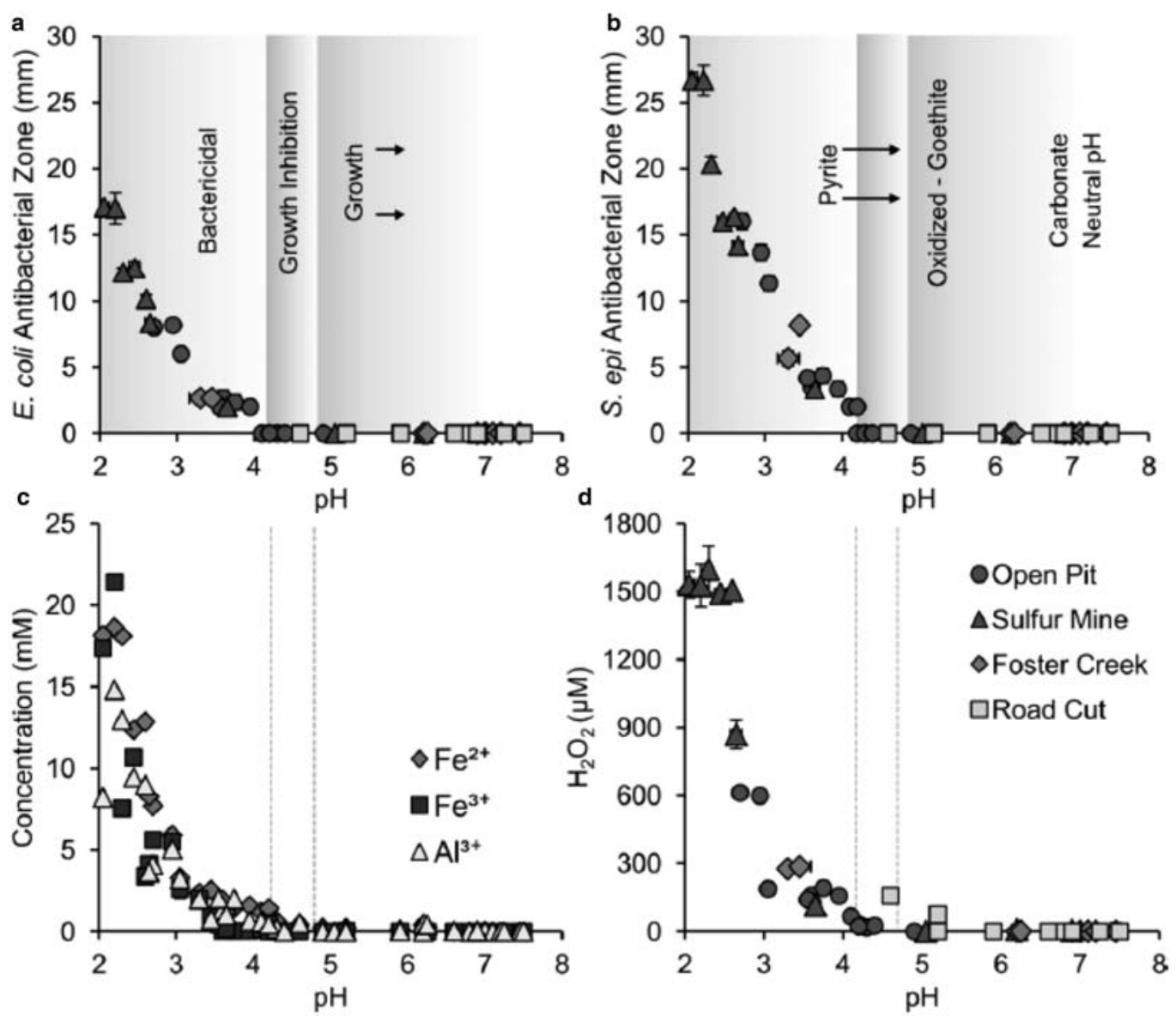

FIG. 13. Trends with $\mathrm{pH}$ in antibacterial effectiveness across the OMT deposit, indicated by zones of inhibition (mm) from clay suspensions (100 mg/mL): (a) Gram-negative E. coli; (b) Gram-positive S. epidermidis; (c) major metals in solution; (d) hydrogen peroxide (from Morrison et al., 2016; open access).

\section{BIOIMA GING}

TEM

Critical point drying of bacteria (see Morrison et al., $2014)$ in time series after incubation $\left(37^{\circ} \mathrm{C}\right)$ with aqueous leachates of the OMT Blue clay, allowed TEM imaging of the $E$. coli cells as they responded to the hydrated clay components (Fig. 15). After $1 \mathrm{~h}$, small black precipitates that were initially on the cell membrane, migrate to the polar ends of the $E$. coli cells (Williams et al., 2011). However, after 24 h, these black precipitates have entered the cell interior, and damage is clearly seen by the formation of voids (white holes), which may be artifacts of the cell microtoming through phosphate granules that pluck out. Such granules are produced as phosphate anions and are used and stored for regulation of cation transport across the cell membrane (Schmidt et al., 2006).

\section{Synchrotron: Scanning Transmission X-ray Microscopy}

Bioimaging of the interaction of $E$. coli in suspensions of the OMT clay and leachate was performed at the Advanced Light Source in Berkeley, California (Lawrence Berkeley National Laboratory, USA; Morrison et al., 2016). Using STXM maps of the bacteria in clay suspensions (in silicon nitride cells), chemical changes in the bacteria and suspensions were monitored over time (12 h). Near-edge X-ray absorption 


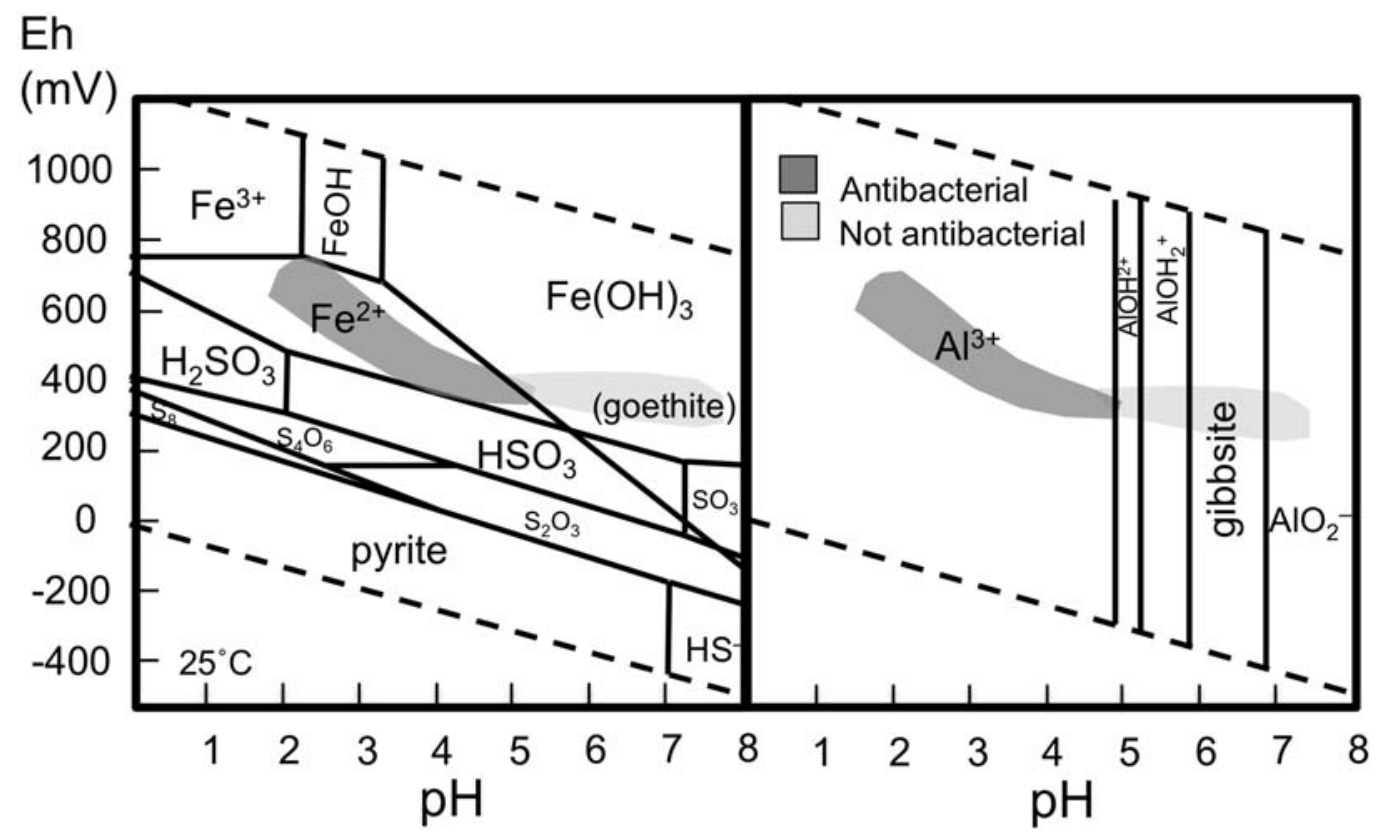

FIG. 14. Eh-pH stability plots at $25^{\circ} \mathrm{C}$ for aqueous: (a) Fe-S-O (modified from Morrison, 2015) and (b) Al-O (data from Takeno, 2005) showing the range of antibacterial and non-antibacterial clay suspensions from the OMT alteration assemblages.

fine structure spectra (NEXAFS) were collected in time series that indicate I-S in association with $E$. coli (Fig. 16a). The $\mathrm{Fe}$ spectra indicate $\mathrm{Fe}^{2+}$-rich clays (Fig. 16b). After $12 \mathrm{~h}$ (Fig. 16c), $\mathrm{Fe}^{2+}$ is attracted to E. coli (green) leaving the solution enriched in $\mathrm{Fe}^{3+}$ (red). This makes sense because E. coli utilize reduced $\mathrm{Fe}$ in their metabolism, while $\mathrm{Fe}^{3+}$ must be reduced by siderophores in order to be transported across the cell membrane (Kammler et al., 1993; Lemire et al., 2013). The important finding was that $\mathrm{Fe}^{2+}$ dominates at the cell membrane and produces ROS that may damage membranes.

\section{Nano-Secondary Ion Mass Spectrometry (SIMS)}

Using Nano-secondary ion mass spectrometry (National SIMS Facility at Arizona State University, USA), the E. coli reacted with OMT clay ( $24 \mathrm{~h}$ ) were further analysed chemically in their glutaraldehydefixed form (Orphan \& House, 2009), mounted on Si wafers. Aqueous $\mathrm{Fe}$ and $\mathrm{Al}$ dominate the OMT Blue clay leachate (Table 2); therefore, we investigated their potential uptake and spatial distribution in E. coli. Use of a $\mathrm{Cs}^{+}$primary ion beam facilitates the spatial resolution needed to study elemental distributions on a scale of $<50 \mathrm{~nm}$; therefore, the negative secondary ion emissions from a $\mathrm{Cs}^{+}$bombardment of the cells was measured using a $1 \mathrm{pA}$ current and $10 \mu \mathrm{m}$ rastered area. Aluminium (measured at mass 54 for ${ }^{27} \mathrm{Al}_{2}{ }^{-}$) dominated on the cell membranes, while $\mathrm{Fe}$ (measured at mass 72 for $\mathrm{FeO}^{-}$) dominated in the intracellular region (Fig. 17). This was the first confirmation that $\mathrm{Al}$ played a role in damage to the $E$. coli cell membranes, in addition to the $\mathrm{Fe}^{2+}$, shown by STXM to be attracted to the membrane.

Morrison et al. (2016) used genotoxicity testing to further evaluate the role of the individual metals in reactions that affected different bacterial proteins. Aqueous $\mathrm{Al}^{3+}$ caused the most damage to cell membrane proteins, compared to intracellular proteins, whereas $\mathrm{Fe}^{2+}$ caused the most damage to DNA. This supported previous observations of damage to both linear and circular DNA indicated by PCR assays of the OMT leachate (Williams et al., 2011).

\section{Electron Energy Loss Spectra (EELS)}

One last piece of evidence that shed light on the order of chemical events in the antibacterial mechanism of the OMT Blue clay was from TEM electron 


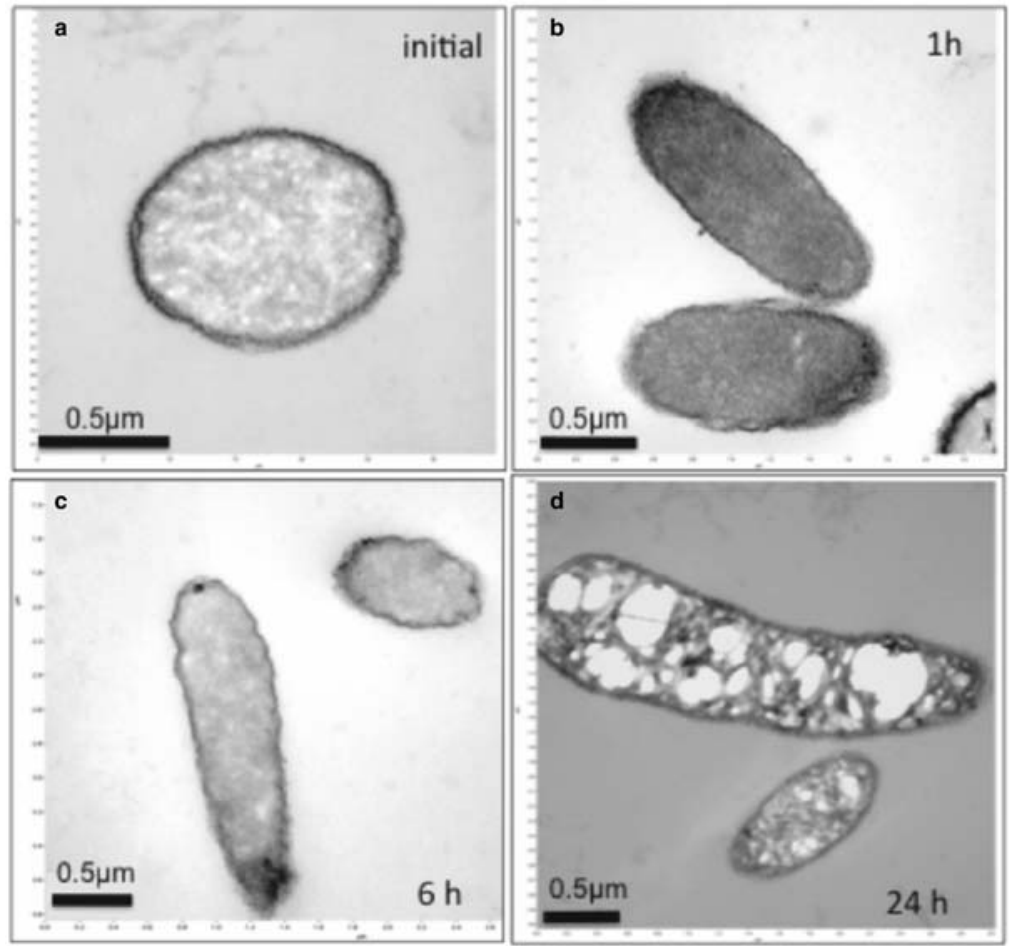

FIG. 15. Time series over $24 \mathrm{~h}$ of $E$. coli reacted with OMT leachate $\left(37^{\circ} \mathrm{C}\right)$ showing morphological changes occurring during the cell destruction (reprinted with permission from Williams et al. (2011). Copyright 2011, the American chemical Society).

energy loss analysis (EEL) of the small black particles found inside the E. coli upon cell death (Fig. 15). The EEL image (Fig. 18) shows those electron-dense areas as white spots, and Morrison et al. (2014) compared the $\mathrm{Fe}^{2+}$ and $\mathrm{Fe}^{3+}$ energy spectra of the white spots to adjacent areas within a single bacterium. It confirmed that the spots were $\mathrm{Fe}^{3+}$, likely precipitates of $\mathrm{Fe}-$ oxides or hydroxides indicating oxidation of the $\mathrm{Fe}^{2+}$ that entered through the cell membrane.

The conclusion supports observations made by others (Gutteridge et al., 1985; Zatta et al., 2002) that $\mathrm{Al}$ and $\mathrm{Fe}$ act together to enhance damage to bacteria. The role of the $\mathrm{Al}^{3+}$, derived from dissolution of aluminosilicates in the clay assemblage (plagioclase, smectite), is to damage proteins in the cell membrane, which may disrupt the metabolic mechanisms that regulate the uptake of $\mathrm{Fe}^{2+}$. Uncontrolled transport of large amounts of $\mathrm{Fe}^{2+}$ across the membrane can be toxic (Repine et al., 1981; Keyer \& Imlay, 1996; Andrews et al., 2003). Evidence for production of ROS was shown by the large amount of hydrogen peroxide generated by the $\mathrm{Fe}^{2+}$ in the aqueous leachates (Fig. 13). However, the cellular destruction (Fig. 15d) is by intracellular $\mathrm{Fe}^{2+}$ oxidation reactions, because hydroxyl radicals do not exist long enough to migrate more than a few nanometers before reacting with biomolecules (Winterbourn, 2008). The distribution of intracellular $\mathrm{Fe}^{3+}$-oxide precipitates is evidence for reactions that occurred within the cell, producing hydroxyl radical damage to proteins (Repine et al. 1981; Morrison et al., 2016).

\section{COLOMBIAN LACUSTRINE CLAY}

Not all antibacterial clays are from hydrothermal environments, where transition metals are abundant and play a dominant role in the toxicity. Recently, Londoño \& Williams (2016) studied a lacustrine clay (Hoorn, 1994) from the Colombian Amazon (AMZ) near Araracuara, that is dominated by kaolins and smectite, with very little $\mathrm{Fe}$ content in the aqueous leachate (Table 2). This clay shows significant dissolution textures (Londoño \& Williams, 2016), in moderately disordered kaolinite (Hinkley Index 0.8). 


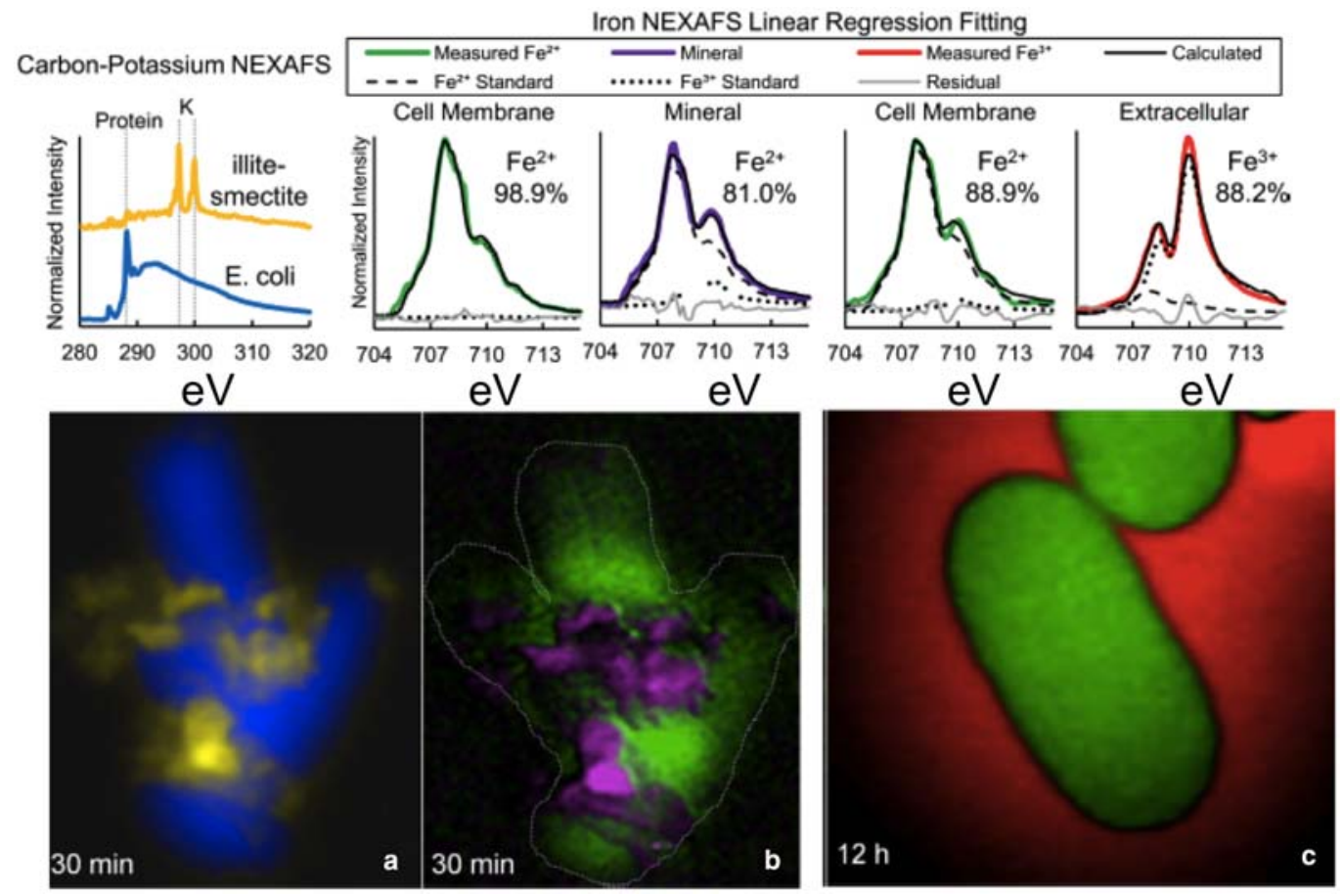

FIG. 16. Near-edge X-ray absorption fine structure mapping of Fe in OMT Blue clay suspensions with $E$. coli (modified from Morrison et al., 2016). (a) I-S (yellow) is indicated by K content on E. coli (blue) after 30 min; (b) Fe ${ }^{2+}$-dominant clays (purple) on $\mathrm{Fe}^{2+}$-enriched cell membranes (green); (c) $\mathrm{Fe}^{2+}$ is attracted preferentially to cells (green) after $12 \mathrm{~h}$, leaving $\mathrm{Fe}^{3+}$-enriched fluid (red).
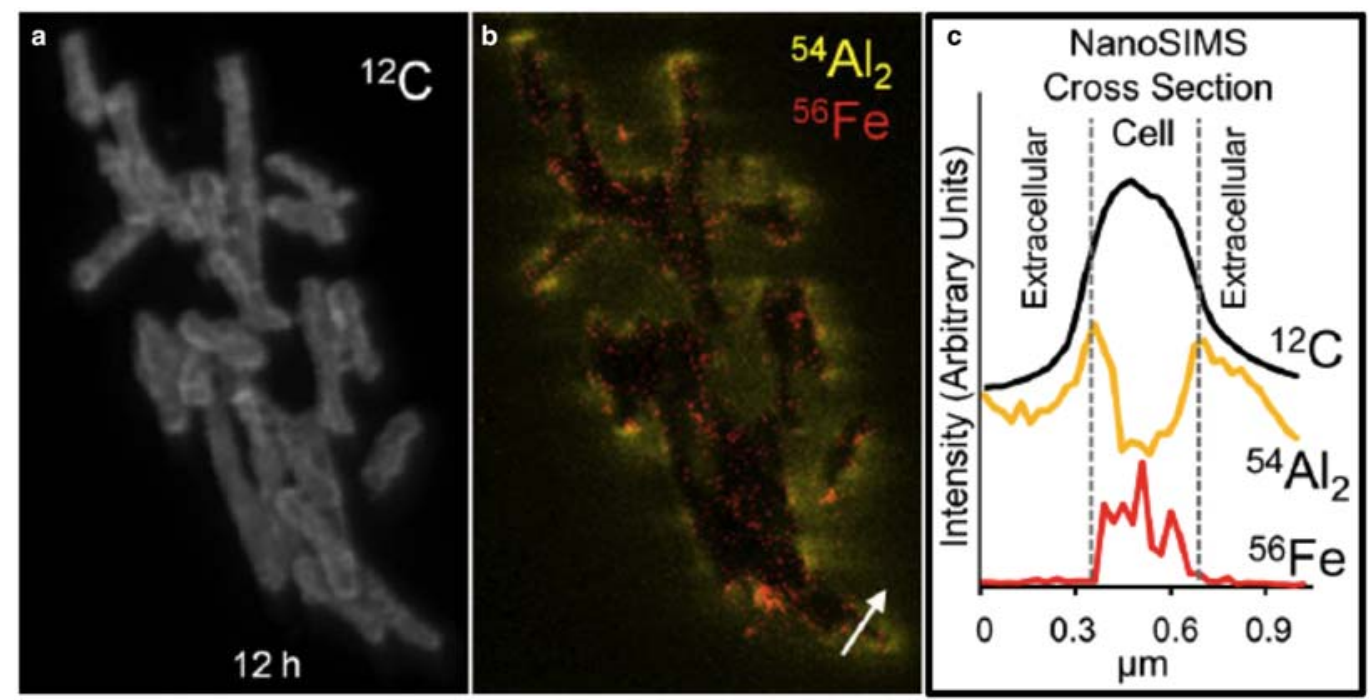

FIG. 17. Nano-SIMS showing: (a) a cluster of E. coli treated with OMT leachate; (b) Al (yellow) and Fe (red) distributions in the E. coli; (c) cross section across a single cell (white arrow in b) showing elevated Al on cell membranes and intracellular Fe (modified from Morrison et al., 2016). 

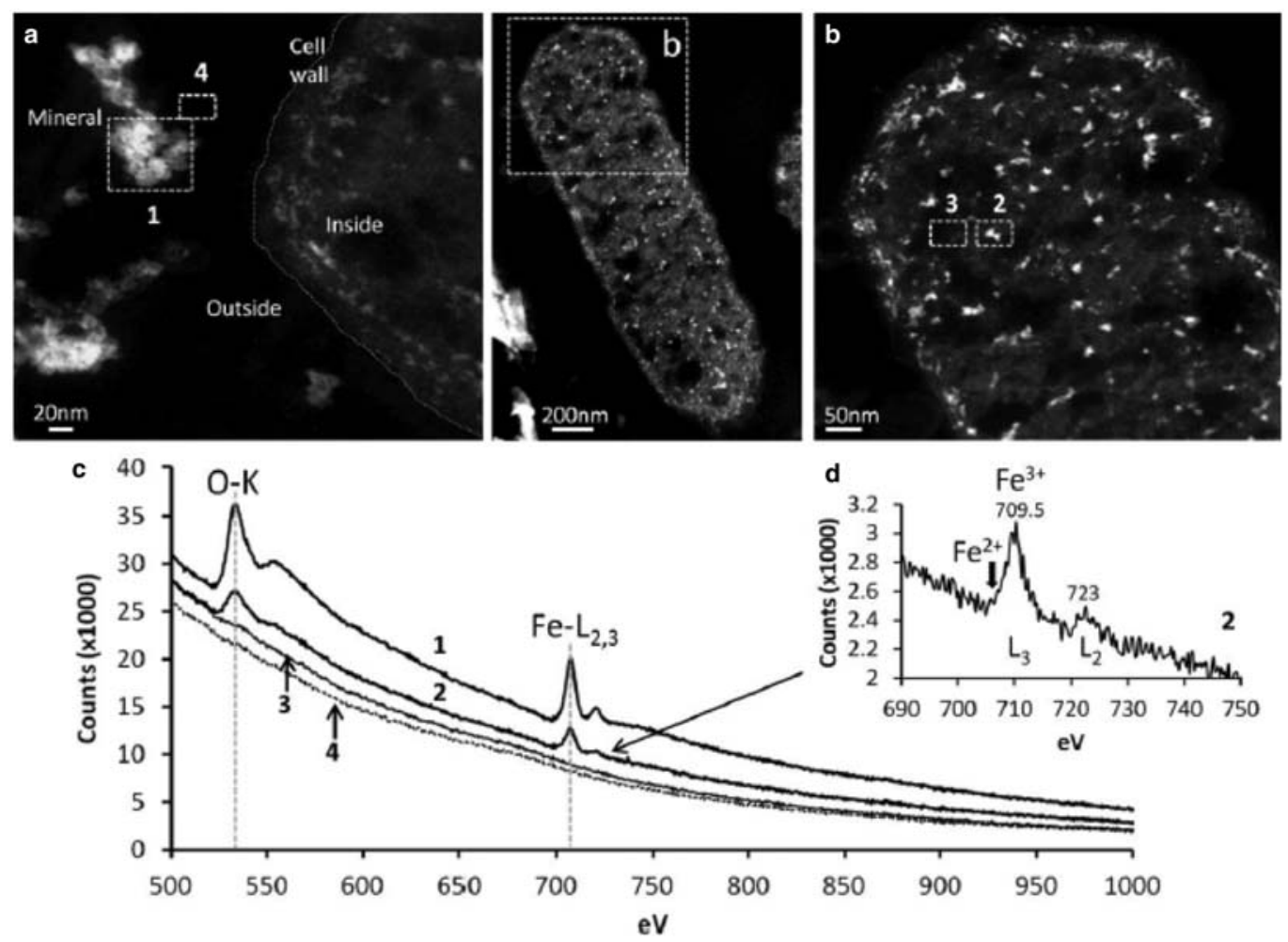

FIG. 18. Electron energy loss study of the opaque precipitates observed in E.coli reacted for $24 \mathrm{~h}$ with OMT leachate (from Morrison et al., 2014): (a) areas 1 and 4 compare mineral to no mineral; (b) close-up of electron-dense area 2, compared to 3 background; (c) EEL spectra for areas 1-4; and (d) close up of energy spectra indicating $\mathrm{Fe}^{3+}$ precipitates.

The AMZ is not as effective as OMT at killing the model bacteria tested (E. coli and B. subtilis), but at higher concentrations ( $300 \mathrm{mg}$ clay $/ \mathrm{mL}$ ) it is bactericidal. Interestingly, the aqueous leachate of the clay is not antibacterial, rather physical proximity of the clay to the cell membrane is required. We tested the physical attraction between the clay and E. coli (model Gram-negative bacteria) and B. subtilis, (model Gram-positive bacteria). The zeta potential (Fig. 19) was negative for all surfaces over the $\mathrm{pH}$ range of $\sim 3$ to 9 , indicating that there should be a repulsion between the minerals and bacteria. At the $\mathrm{pH}(\sim 4.6)$ buffered naturally by the clay there was a repulsion greater than $17 \mathrm{mV}$ between the clay and the bacteria; therefore one may conclude that the negative surface potentials affect the competition for cations that could be nutrients or toxins to the bacteria.

Unlike the OMT Blue antibacterial clay, when the AMZ is reacted with E. coli, the bacteria lose $\mathrm{P}$ and $\mathrm{Mg}$, and gain $\mathrm{Al}$. There is no other significant exchange of elements, so initially we thought that the clay was absorbing nutrients from the bacteria, causing their population decline (Londoño \& Williams, 2016). However, addition of excess $\mathrm{P}$ and $\mathrm{Mg}$ to the growth media did not re-establish bacterial growth; the bacteria died even in the presence of sufficient nutrients. This

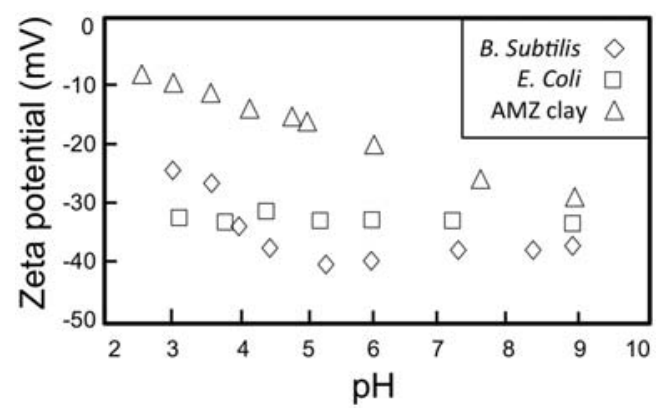

FIG. 19. Zeta potential of two model bacterial pathogens compared to the AMZ clay suspension in DIW (equilibrated for $24 \mathrm{~h}$ ). 

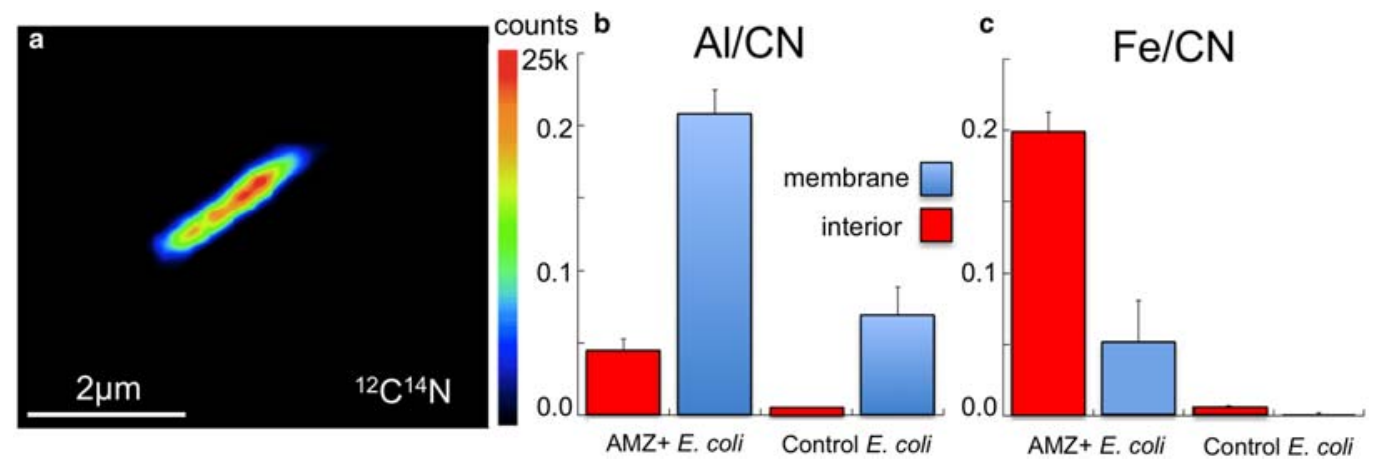

FIG. 20. NanoSIMS measurement of Al and Fe distribution in E. coli treated with AMZ clay. Negative ion counts of: (a) matrix $\mathrm{CN}^{-}$; (b) $\mathrm{Al} / \mathrm{CN}$ ratios in the $\mathrm{AMZ}$-treated E. coli compared to untreated control; and (c) $\mathrm{Fe} / \mathrm{CN}$ ratios accumulated over membrane $v$ s. interior.

led to the hypothesis that $\mathrm{Al}$ was damaging these cell membranes, releasing $\mathrm{P}$ from phospholipids in the cell membrane (Londoño et al., 2017).

In order to evaluate the potential uptake of $\mathrm{Al}$ by the bacteria reacted with AMZ, NanoSIMS ion imaging of E. coli reacted with $\mathrm{AMZ}$ was performed similar to the previous study on OMT Blue clay. Here we normalized the elements of interest to the matrix $(\mathrm{CN})$. To avoid a potential topographic effect of the ion distribution from the non-flat, cylindrically shaped bacteria, instead of taking cross sections we rastered $\left(10 \mu \mathrm{m}^{2}\right)$ over the entire cell and collected depth-profiles through the cells (e.g. Orphan \& House, 2009), from the top membrane of the bacteria (mounted on a $\mathrm{Si}$ wafer), through the interior and into the lower membrane (Fig. 20). WinImage ${ }^{\mathrm{TM}}$ software on the Cameca $50 \mathrm{~L}$ NanoSIMS allows users to select regions of interest and accumulate (integrate) the pixels in a volume under that region. Therefore, we can evaluate qualitatively the counts of ions coming from the cell interior $v s$. the cell membranes. Quantification is not possible without measuring a standard of each element within the same matrix. While $\mathrm{CN}$ molecules are major components of bacterial membranes and intracellular components, their molecular composition varies significantly; therefore, the sputtering rate (release of secondary ions) may change as a function of the matrix composition (Wilson et al., 1989). Nonetheless, by normalizing each ionic species of interest to the major component of the matrix, one can evaluate the relative distribution of elements of interest.

Results from E. coli cells reacted with AMZ clay were compared to control $E$. coli grown without clay, and clear differences in the cell compositions were observed (Fig. 20). There is an increase in the $\mathrm{Al} / \mathrm{CN}$ ratio of the bacterial membrane compared to the control, and slightly higher $\mathrm{Al} / \mathrm{CN}$ in the cell interior than the control. $\mathrm{Al}^{3+}$ is not known to penetrate living bacterial membranes without a chelator that promotes its transport into the cell (Guida et al., 1991; Williams, 1999). However, if the membranes are damaged by toxic $\mathrm{Al}$ concentrations, as indicated by the release of $\mathrm{P}$ from the bacteria, then Al may have entered the cell interior post-mortem.

The $\mathrm{Fe} / \mathrm{CN}$ ratios show a 20 -fold increase in the intracellular Fe of the AMZ-treated E. coli over the untreated control E. coli. This is surprising because Fe is not one of the major transition metals of the aqueous leachates of the AMZ clays, yet it does show elevated concentrations in AMZ leached with growth media (LB), along with $\mathrm{Cu}, \mathrm{Zn}$ and $\mathrm{Mn}$ (Londoño et al., 2017). This points to a role of ionic strength in the sequestration of toxic metals from clays. Individually, the metals are not antibacterial at the $\mathrm{pH} 4.6$ buffered by the clay. However, combined, they were shown to be antibacterial. NanoSIMS analyses of $\mathrm{Cu} / \mathrm{CN}$ showed no significant difference between the AMZ-reacted $E$. coli and the control due to low ionization of the negative secondary $\mathrm{Cu}$ ions.

\section{FUTURE MEDICAL APPLICATIONS}

At this point, research on the specific minerals, chemical conditions, and mechanisms by which natural clays kill human pathogens has implicated the important role of soluble metals in the process, and the equally important role of the clay minerals in buffering aqueous conditions to keep metals in solution long enough for oxidation reactions to impact the bacterial defenses. The next critical step is to evaluate the effect 
of these clays on skin cells, both in vitro and in vivo. While $\mathrm{mM}$ levels of hydrogen peroxide indicate significant production of ROS during the oxidation of soluble metals, skin cells have their own supply of oxygen through blood vessels that may help to maintain the cellular functions in the presence of elevated aqueous ROS (Hyslop et al., 1995). The fact that the bacteria are 'planktonic' (floating organisms in water), rather than integrated into a living organ makes them more vulnerable to the kind of attack demonstrated by the antibacterial clays described. Therefore, testing of the clay effect on pathogenic biofilms is a priority.

The topical application of natural antibacterial clays to wounds comes with the inherent risk of nanoparticulate silicates that can potentially migrate into the bloodstream, where cases of thrombosis (lung, brain) have been documented (Baker et al., 2007, Lawton et al., 2009). This is true of any particulate material, but the risks must be assessed. In general, the salinity of the clay poultices will cause aggregation of nanoparticles that could render them large enough to be unable to penetrate the vascular system. Alternatively, efforts can be made to eliminate the nanoparticulate fraction from the clay before application, which could be done by gravimetric settling of the coarser $(>0.1 \mu \mathrm{m}$ fraction) clays through water, then siphoning off the suspended fine particles.

Note that daily internal use of natural clays for long periods of time can be hazardous to health. Clay minerals have an enormous surface area that interacts with the aqueous environment. The antibacterial clays studied here are thought to have formed in hydrothermal environments where volcanogenic waters may carry and incorporate metals into the minerals that precipitate. Associated with hydrothermal systems are elements that are toxic in low doses (e.g. As, $\mathrm{Hg}$ ) if they are in bioavailable forms, and can easily adsorb to clay mineral surfaces, especially in interlayers, where they may be preserved until hydration for a medical use. While the use of antibacterial clays for topical wound care may be tolerated in the short term, the long-term ingestion of clays, often promoted online by unregulated Neutraceutical companies, could lead to accumulation of bioavailable toxins in the body.

The identification of volcanogenic hydrothermal alteration assemblages as a primary depositional environment for clays with antibacterial properties should lead to more discoveries of antibacterial clay deposits worldwide (Londoño \& Williams, 2016; Morrison et al., 2016). While this could provide a new economic outlet for such reserves, the application to human health requires further study to understand interactions with human tissues, and potential side effects. Nonetheless, by evaluating antibacterial clays and mimicking the natural geochemical processes (geomimicry) recognized and utilized by our ancestors, we may discover new solutions for treating antibiotic-resistant bacteria.

\section{ACKNOWLEDGEMENTS}

I am indebted to my PhD students, K.D. Morrison and S.C. Londoño, whose collaboration on this research has been vital, and to my colleague D.D. Eberl (USGS), for his continuing support. The National Institutes of Health (NIH R21-AT003618, 2006) funded the pilot study on French green clay. M. Holland performed the first in vitro antibacterial testing followed by S. Haydel and USGS collaborators, D. Metge, R. Harvey and J. Underwood. Subsequent funding from the National Science Foundation (EAR-1123931) supported research on Oregon Blue clay. R. Misra directed the microbiology. S. Williams advised the fieldwork. Dissertations by K. Morrison, S. Londoño and research assistance from A. Haddad, X. Chen, C. Tommimabry are acknowledged gratefully along with technical assistance from M. Bose, D. Lowry, R. Robertson, T. Groy, L. Garvie, S. Romaniello, G. Gordon, A. Poret-Petersen. S.C. Londoño was supported by Colfuturo, Colciencias, Colombia. Oregon Mineral Technologies, The Clay Minerals Society, the Geological Society of America, ARCS Foundation and International Medical Geology Association and ASU partially supported student research. This review is dedicated to the memory of Line Brunet de Courssou.

\section{REFERENCES}

Amyes S., Miles R.S., Thomson C.J. \& Tillotson G. (1996) Antimicrobial Chemotherapy. CRC Press, Taylor \& Francis Group, Boca Raton, Florida, USA, $72 \mathrm{pp}$.

Andrews S.C., Robinson A.K. \& Francisco R.-Q. (2003) Bacterial iron homeostasis. FEMS Microbiology Reviews, 27, 215-237.

Bacon C.R. \& Nathenson M. (1996) Geothermal resources in the Crater Lake area, Oregon. U.S. Geological Survey Open-File Report, 96-663.

Baker S.E., Sawvel A.M., Zheng N. \& Stucky G.D. (2007) Controlling bioprocesses with inorganic surfaces: Layered clay hemostatic agents. Chemistry of Materials, 19, 4390-4392.

Barbusinski K. (2009) Fenton reaction: Controversy concerning the chemistry. Ecological Chemistry and Engineering, 16, 347-358. 
Bauer A.W., Kirby W.M.M., Sherris J.C. \& Turck M. (1966) Antibiotic susceptibility testing by a standardized single disk method. American Journal of Clinical Pathology, 45, 493-496.

Carretero M.I., Gomes C.S.F. \& Tateo F. (2013) Clays and human health. Pp. 717-741 in: Handbook of Clay Science, 2nd edition (F. Bergaya \& G. Lagaly, editors). Developments in Clay Science 5, Elsevier, Amsterdam.

CLSI, Clinical Laboratory Standards Institute (2015) Methods for Dilution Antimicrobial Susceptibility Tests for Bacteria That Grow Aerobically; Approved Standard - tenth edition. Wayne, Pennsylvania, USA, CLSI document M07-A10, 35, pp. 1-45.

Cohn C.A., Pak A., Strongin D. \& Schoonen M.A. (2005) Quantifying hydrogen peroxide in iron containing solutions using leuco-crystal violet. Geochemical Transactions, 6, 47-51.

Eberl D.D. (2003) User's guide to RockJock; A program for determining quantitative mineralogy from powder $X$-ray diffraction data. U.S. Geological Survey OpenFile Rep. 2003-78, 47 pp.

Fenton H.J.H. (1894) Oxidation of tartaric acid in presence of iron. Journal of Chemical Society Transactions, 65, 899-911.

Ferrell Jr. R.E. (2008) Medicinal clay and spiritual healing. Clays and Clay Minerals, 56, 751-760.

Foster J.W. and Woodruff H.B. (2010) Antibiotic substances produced by bacteria. Annals of the New York Academy of Science, 2013, 125-136.

Friedlander L.R., Puri N., Schoonen M.A.A. \& Karzai W. (2015) The effect of pyrite on Escherichia coli in water: proof-of-concept for the elimination of waterborne bacteria by reactive minerals. Journal of Water Health, 13.1, 42-53.

George K.M., Chatterjee D., Gunawardana G., Welty D., Hayman J., Lee R. \& Small P.L.C. (1999) Mycolactone: a polyketide toxin from Mycobacterium ulcerans required for virulence. Science, 283, 854-7.

Guida L., Saidi Z., Hughes M. \& Poole R. (1991) Aluminum toxicity and binding to Escherichia coli. Archives of Microbiology, 156, 507-512.

Gutteridge J.M., Quinlan G.J., Clark I. \& Halliwell B. (1985) Aluminium salts accelerate peroxidation of membrane lipids stimulated by iron salts. Biochimica et Biophysica Acta - Lipids and Lipid Metabolism, 835, 441-447.

Haydel S.E., Remenih C.M. \& Williams L.B. (2008) Broad-spectrum in vitro antibacterial activities of clay minerals against antibiotic-susceptible and antibioticresistant bacterial pathogens. Journal of Antimicrobial Chemotherapy, 61, 353-361.

Hoogerheide J.C. (1944) Antibiotic substances produced by soil bacteria. Botanical Review, 10, 599-638.

Hoorn C. (1994) Fluvial palaeoenvironments in the intracratonic Amazonas Basin (early Miocene-early
Middle Miocene, Colombia). Palaeogeography \& Palaeoclimate, 109, 1-54.

Hyslop P.A., Hinshaw D.B., Scraufstatter I.U., Cochrane C.G., Kunz S. \& Vosbeck K. (1995) Hydrogen peroxide as a potent bacteriostatic antibiotic: implications for host defense. Free Radical Biology and Medicine, 19, 31-37.

Kammler M., Schön C. \& Hantke K. (1993) Characterization of the ferrous iron uptake system of Escherichia coli. Journal of Bacteriology, 175, 6212-6219.

Keyer K. \& Imlay J.A. (1996) Superoxide accelerates DNA-damage by elevating free-iron levels. Proceedings of the National Academy of Sciences, USA, 193, 13635-13649.

Kibanova D., Nieto-Camacho A. \& Cervini-Silva J. (2009) Lipid peroxidation induced by expandable clay minerals. Environmental Science \& Technology, 43, 7550-7555.

King G.M., Weber C.F., Ohta H., Sato Y. \& Nanba K. (2008) Molecular survey and activities of carbon monoxide oxidizing bacteria on volcanic deposits in Miyake-jima, Japan. Microbes \& Environments, 23, 299-305.

Konhauser K.O. \& Urrutia M.M. (1999) Bacterial clay authigenesis: a common biogeochemical process. Chemical Geology, 161, 399-413.

Kvitko B.H., Goodyear A., Propst K.L., Dow S.W. \& Schweizer H.P. (2012) Burkholderia pseudomallei known siderophores and Hemin uptake are dispensable for lethal Murine Melioidosis. Public Library of Science: Neglected Tropical Diseases, 6, e1715.

Lawton G., Granville-Chapman J. \& Parker P.J. (2009) Novel hemostatic dressings. Journal of the Royal Army Medical Corps, 155, 309-314.

Lemire J.A., Harrison J.J. \& Turner R.J. (2013) Antimicrobial activity of metals: mechanisms, molecular targets and applications. Nature Reviews 11, 371-384.

Londoño S.C. \& Williams L.B. (2016) Unraveling the antibacterial mode of action of a clay from the Colombian Amazon. Environmental Geochemistry \& Health, 38, 363-379.

Londoño S.C., Hartnett H.H. \& Williams L.B. (2017) The antibacterial activity of aluminum in clay from the Colombian Amazon. Environmental Science \& Technology. doi: 10.1021/acs.est.6b04670.

Marsollier L., Rober R., Aubry J., Saint André J-P., Kouakou H., Legras P., Manceau A.-L., Mahaza C. \& Carbonnelle B. (2002) Aquatic insects as a vector for Mycobacterium ulcerans. Applied \& Environmental Microbiology, 68, 4623-4628.

Moore D.M. \& Reynolds R.C. (1997) X-ray Diffraction and the Identification and Analysis of Clay Minerals, 2nd edition. Oxford University Press, New York. 
Morrison K.D. (2015) Unearthing the antibacterial activity of a natural clay deposit. $\mathrm{PhD}$ dissertation, Arizona State University, Arizona, USA, 157 pp.

Morrison K.D., Underwood J.C., Metge D.W., Eberl D.D. \& Williams, L.B. (2014) Mineralogical variables that control the antibacterial effectiveness of a natural clay deposit. Environmental Geochemistry \& Health, 36, 613-631.

Morrison K.D., Misra R. \& Williams L.B. (2016) Unearthing the antibacterial mechanism of medicinal clay: A geochemical approach to combating antibiotic resistance. Nature Scientific Reports, 5, 19043; doi: 10.1038/srep 19043.

Nies D.H. (1999) Microbial heavy-metal resistance. Applied Microbiology \& Biotechnology, 51, 730-750.

Orphan V.J. \& House C.H. (2009) Geobiological investigations using secondary ion mass spectrometry: microanalysis of extant and paleo-microbial processes. Geobiology, 7, 360-372.

Portaels F., Meyers W.M., Ablordey A., Castro A.G., Chemlal K. (2008) First cultivation and characterization of Mycobacterium ulcerans from the environment. Public Library of Science Neglected Tropical Diseases 2, e178. doi: 10.1371/journal.pntd.0000178.

Prousek J. (2007) Fenton chemistry in biology and medicine. Pure \& Applied Chemistry, 79, 2325-2338.

Repine J.E., Fox R.B. \& Berger E.M. (1981) Hydrogen peroxide kills Staphylococcus aureus by reacting with Staphylococcal iron to form hydroxyl radicals. Journal of Biological Chemistry, 256, 7094-7096.

Rimstidt J.D. \& Vaughan D.J. (2003) Pyrite oxidation: A state-of-the-art assessment of the reaction mechanism. Geochimica et Cosmochimica Acta, 67, 873-880.

Schmidt D., Jiang Q. \& McKinnon R. (2006) Phospholipids and the origin of cationic gating charges in voltage sensors. Nature, 444, 775-779.

Schoonen M.A.A., Harrington A.D., Laffers R. and Strongin D.R. (2010) Role of hydrogen peroxide and hydroxyl radical in pyrite oxidation by molecular oxygen. Geochimica et Cosmochimica Acta, 74, 4971-4987.

Takeno N. (2005) Atlas of Eh-pH diagrams: Intercomparison of thermodynamic databases. Geological Survey of Japan Open File Report No. 419, 285 pp.

Vermeer D.E. \& Ferrell Jr, R.E. (1985) Nigerian geophagical clay: A traditional antidiarrheal pharmaceutical. Science, 227, 634-636.

Weber C.F. \& King G.M. (2010) Quantification of Burkholderia coxL genes in Hawaiian volcanic deposits. Applied Environmental Microbiology, 76, 2212-2217.
Wei J.-C., Yen Y.-T., Su H.-L. \& Lin J.-J. (2011) Inhibition of bacterial growth by the exfoliated clays and observation of physical capturing mechanism. The Journal of Physical Chemistry C, 115, 18770-18775.

WHO, World Health Organization (2008) Buruli ulcer disease (Mycobacterium ulcerans infection). World Health Organization. http://www.who.int/ mediacentre/factsheets/fs199/en/

Williams R.J.P. (1999) What is wrong with aluminum? Journal of Inorganic Biochemistry, 76, 81-88.

Williams L.B. \& Haydel S.E. (2010) Evaluation of the medicinal use of clay minerals as antibacterial agents. International Geology Review, 52, 745-770.

Williams L.B. \& Hillier S. (2014) Kaolins and health: from first grade to first aid. Elements, 10, 207-211.

Williams L.B., Holland M., Eberl D.D., Brunet T. \& Brunet de Courssou L. (2004) Killer clays! Natural antibacterial clay minerals. Mineralogical Society Bulletin, 139, 3-8.

Williams L.B., Haydel S.E., Giese R.F. \& Eberl D.D. (2008) Chemical and mineralogical characteristics of French green clays used for healing. Clays and Clay Minerals, 56, 437-452.

Williams L.B., Metge D.W., Eberl D.D., Harvey R.W., Turner A.G., Prapaipong P. \& Poret-Peterson A.T. (2011) What makes natural clays antibacterial? Environmental Science \& Technology, 45, 3768-3773.

Wilson M.J. (2003) Clay mineralogical and related characteristics of geophagic materials. Journal of Chemical Ecology, 29, 1525-1547.

Wilson R.G., Stevie F.A. \& Magee C.W. (1989) Secondary Ion Mass Spectrometry: A Practical Handbook for Depth Profiling and Bulk Impurity Analysis. Wiley Interscience Publishers, New York, 384 pp.

Winterbourn C.C. (2008) Reconciling the chemistry and biology of reactive oxygen species. Natural Chemical Biology, 4, 278-286.

Yokoyama S., Kuroda M. \& Sato T. (2005) Atomic force microscopy study of montmorillonite dissolution under highly alkaline conditions. Clays and Clay Minerals, 53, 147-154.

Young S.L. (2011) Craving Earth. Columbia University Press, New York, 228 pp.

Zatta P., Kiss T., Suwalsky M. \& Berthon G. (2002) Aluminium (III) as a promoter of cellular oxidation. Coordination Chemistry Reviews, 228, 271-284.

Zeelmaekers E., McCarty D. \& Mystkowski K. (2009) Sybilla User Manual, Chevron ${ }^{\circledR E T C ~ p r o p r i e t a r y ~}$ software. 16 pp. 